The Year 2000 International Research

Conference on Social Security

Helsinki, 25-27 September 2000

"Social security in the global village"

ISSA • AISS • IVSS

\title{
Globalization and the welfare state
}

Constraints, challenges and vulnerabilities

Fritz W. SCHARPF

Professor, Max-Planck-Institut für Gesellschaftsforschung

Köln, Germany

INTERNATIONAL SOCIAL SECURITY ASSOCIATION (ISSA) RESEARCH PROGRAMME

CONFERENCE HOSTS: FINNISH ISSA MEMBER ORGANIZATIONS 


\title{
Globalization and the welfare state Constraints, challenges and vulnerabilities ${ }^{1}$
}

\author{
Fritz W. Scharpf \\ Professor \\ Max-Planck-Institut für Gesellschaftsforschung, Köln \\ Germany
}

The advanced capitalist welfare states developed their characteristic aspirations, policy patterns, sources of finance, and institutional structures in the decades following World War II under conditions in which the nation state was able to exercise a historically exceptional degree of control over its own economic boundaries. As governments were able to regulate capital movements, to determine exchange rates, and to adjust tariffs on imports, external economic factors had little or no influence on domestic policy choices. Thus, if there are commonalities among "families" of national welfare states and industrial-relations systems (Esping-Anderson, 1990) , they were primarily due to shared ideological world views and aspirations among dominant political parties. Politics, in other words, did matter very much in the postwar decades.

These cozy conditions changed after the early 1970s, when the viability of advanced capitalist economies was severely tested by the stagflation crisis following the first oil-price shock. As it turned out, countries differed greatly in their capacity to cope with the new international turbulence that was exacerbated by the destruction of the Bretton-Woods regime of fixed but adjustable exchange rates. Countries that failed to find effective responses found themselves confronted by rising mass unemployment and/or runaway inflation and, in any case, high publicsector deficits at the onset of the second oil-price crisis in the early 1980s which added a

\footnotetext{
${ }^{1}$ This paper is based on some of the findings of a large-scale cooperative research project studying the adjustment of 12 advanced welfare states to changes in the international economic environmentin the period from the early 1970 s to the late 1990s. The project, jointly directed by Vivien A. Schmidt of Boston University and myself and jointly financed by the Volkswagen Foundation, the Thyssen Foundation and the Max-Planck Society, includes reports on the United Kingdom by Martin Rhodes, on Australia and New Zealand by Herman Schwartz, on Switzerland by Giuliano Bonoli and André Mach, on Austria, Belgium and the Netherlands by Anton Hemerijck, Brigitte Unger and Jelle Visser, on Germany by Philip Manow and Eric Seils, on France by Jonah Levy, on Italy by Maurizio Ferreraand Elisabetta Gualmini, and on Sweden and DenmarkbyMats Bennerand Torben Vad. In addition, someimportantissues thatcould notbe fullyexplored in single-country reports were examined in special studies on the participation of women in the labor market by Mary Daly, on early exit from the labor market by Bernhard Ebbinghaus, on the consequences of public-service liberalization by Adrienne Héritierand Susanne Schmidt, and on international taxcompetition bySteffen Ganghof. In addition, Anton Hemerijck, Martin Schludi, VivienSchmidtand I have provided comparative analyses focusing on differences in vulnerabilities and institutional capabilities, sequences ofpolicylearning, and legitimating discourses. The wholeset of studies is presently being published:Fritz W. Scharpf and Vivien A. Schmidt, eds. 2000: Welfare and Work in the Open Economy. Vol. I: From Vulnerability to Competitiveness. Vol. II: Diverse Responses to Common Challenges. Oxford: Oxford University Press. Since the present papercan onlyprovide a greatlyoversimplified interpretation, I alone am responsible for errors of judgment and of omission.
} 
dramatic rise in real interest rates in international capital markets in response to the external challenges they had to meet.

In the present paper, I will omit the analysis of successful and failed responses to the international macro-economic challenges of the $1970 \mathrm{~s}$ and early $1980 \mathrm{~s},{ }^{2}$ and will focus exclusively on the adjustment of employment and welfare systems to challenges arising from the international (global and European) integration of product and capital markets that had slowly increased after the 1960s, but reached new levels of intensity in the late 1980s and 1990s. In doing so, I am quite aware of the fact that international economic changes are not the only ones with which welfare states have to cope during this period, and that changing gender roles and family structures, rapidly aging populations, and the rising costs of health care would have challenged golden-age welfare states even in the absence of "globalization" and the European Monetary Union (EMU). Nevertheless, in the absence of new international constraints on policy choices, these endogenous challenges would be much easier to deal with.

\section{The new constraints}

In the comparative political economy literature, there is considerable dispute over the question of whether economic globalization does, or does not affect welfare-state policy at the national level. While some of this literature is alarmist in tone, predicting a race to the bottom in standards of social protection as a consequence of international regulatory and tax competition (Rodrik, 1997; Steinmo, 1994; Strange, 1991; 1996; Tanzi, 1995), others find no statistical evidence for the predicted convergence but, rather, a continuation of national differences determined by partisan preferences (Garrett, 1995; 1998; Quinn, 1997; Rhodes, 1996; Swank, 1997). If this dispute seems to have generated more heat than light, the reason may be a lack of clarity over two basic distinctions - between binding constraints and price effects on the one hand, and between effects on policy instruments and policy outcomes on the other hand.

Thus, the dramatic rise of real interest rates in the international capital markets in the early 1980s did not prevent countries from running high fiscal deficits - but it surely did raise the costs of the debt service. Similarly, more intense competition in internationalized product markets does not rule out aggressive real wage strategies by national unions, but it raises their costs in terms of job losses. Moreover, where international integration does in fact impose legally binding constraints, as it does for the monetary and exchange-rate policies of member states of the European Monetary Union, these constraints rule out the choice of specific policy instruments, rather than policy outcomes. Hence, even if devaluation and deficit spending are no longer an option, social benefits or public-sector employment may still be increased if they are paid for through higher taxes or the reduction of other expenditures. In short, price effects do not strictly determine the choice of policy instruments, and even binding constraints on policy instruments need not lead to convergent policy outcomes.

Logically, therefore, empirical findings showing persistent national differences of policy outcomes achieved, or policy instruments employed, could not falsify the claim that advanced welfare states are severely challenged by the global or European integration of product and capital markets. Instead, it seems more instructive to consider first the differences between the international (legal and economic) policy environment of the late 1990s and conditions at the

\footnotetext{
${ }^{2}$ These analyses are of course part of the project and fully represented in our book publications.
} 
end of the "golden age" in the late 1960s, and then to relate these differences to the employment and social-policy aspirations of advanced welfare states.

In the early postwar period of "embedded liberalism" (Ruggie, 1982), national economies had been only weakly coupled to their international environment and national governments were still able to control capital transfers, exchange rates, and the conditions under which goods and services could be imported and exported - which allowed them considerable freedom in shaping national systems of employment, taxation, regulation, and welfare provision. More specifically, even in the 1970s and early 1980s, when the international economic environment lost its benign character, governments were still able to resort to a wide range of policy options that are no longer available today. To list a few:

- Britain, Sweden, Italy, Australia, New Zealand and other countries frequently attempted to restore international competitiveness through politically determined devaluations of their currencies;

- in the 1970s, a majority of countries still relied on exchange controls to prevent capital outflows;

- during the first oil-price crisis, most advanced industrial economies attempted to stimulate productive investments through monetary policies ensuring very low, and often negative, real interest rates;

- during the first oil-price crisis, most advanced industrial countries tried to stabilize aggregate demand through spending and investment programs financed by massive fiscal deficits;

- $\quad$ Australia and New Zealand supported full employment by promoting import-substituting industrialization that was protected by extremely high tariff barriers and quantitative restrictions on imports;

- Italy, France and other European countries frequently imposed special tariffs and quantitative restrictions to protect specific branches that were threatened by import competition;

- $\quad$ Sweden and some other countries had highly regulated credit markets that allowed them to channel consumer demand and investment funds to specific sectors, regions or firms;

- Austria, France, Germany and other countries used their influence on state-owned banks for the same purpose;

- Austria, France and Italy did use a large range of nationalized industries as an employment buffer in the first oil-price crisis, and Sweden nationalized its crisis-ridden shipbuilding and steel industries in order to ease the transition to new employment opportunities in other branches;

- $\quad$ practically all countries did subsidize declining industries in order to reduce job losses;

- $\quad$ in all countries, public service functions in telecommunications, transport, energy supply, etc. were protected not only against international, but also against national market competition;

- practically all countries protected national producers by requiring importers to comply with nationally specific product regulations;

- $\quad$ Austria, Germany, Switzerland and other countries did exclude foreign workers in order to reduce open unemployment in the first oil-price crisis.

It should be understood that I am not suggesting that the use of these policy options was then, or would now be, generally desirable. The fact is, nevertheless, that less than two decades ago, many countries found them useful under certain circumstances, and that they would no longer be available today. In Europe, they are ruled out by Featy obligations, enforced as the supreme 
law of the land, that ensure the free movement of goods, services, capital and labor among the member states of the Community. Moreover, European rules have replaced national product standards or required their mutual recognition; they have required the liberalization, deregulation and in effect, privatization of public utilities in communications, transport, and energy supply; European competition law has drastically limited the range of permissible subsidies; the Maastricht criteria for joining the Monetary Union have practically eliminated deficit spending as a policy tool; and the realization of the Monetary Union has completely removed monetary policy and exchange rate policy from the control of its member states.

For countries outside of the European Union, legal constraints are not as tight, but even there the Uruguay Round of GATT (General Agreement on Tariffs and Trade) negotiations has considerably extended existing obligations to free trade in services and in agricultural markets, and the creation of the World Trade Organization (WTO) has increased the legal effectiveness of these obligations. Moreover, countries that became dependent on World Bank and International Monetary Fund (IMF) support faced strong external pressures to implement fiscal consolidation, hard-currency policies, and unrestricted capital exchange; and even in the absence of explicit IMF pressures, policies adopted by Australia and New Zealand after the late 1980s are fully compliant with prescriptions of the "Washington consensus". In Europe, the same is true of Sweden, Denmark and the United Kingdom, that did not choose to join the Monetary Union, but whose fiscal and monetary policies were nevertheless fully compatible with the Maastricht criteria of EMU membership.

Instead it seems that legal pressures are reinforced, and may be even be replaced by economic pressures once the de-facto openness of economies has passed a certain threshold. The constraints on macro-economic policy and the pressure to liberalize capital-exchange policies were particularly severe in countries that depend on capital imports to finance large budget deficits or persistent current-account deficits. But as capital became more mobile, and as the relative importance of international competition in the markets for goods and services increased, economic constraints were felt in a whole range of other policy areas as well. At the most abstract level, these may be described as follows:

- $\quad$ since consumers have a free choice among domestic and imported products, market shares will be lost if national taxes, regulations, and collective-bargaining agreements increase the relative price of domestically produced goods and services;

- $\quad$ since firms have a free choice among production locations, jobs will be lost if national taxes, regulations and collective-bargaining agreements increase the relative costs of domestic production;

- $\quad$ since capital has become internationally mobile, productive investment will decline if national taxes, regulations and collective-bargaining agreements reduce relative post-tax profits; and

- $\quad$ since capital has become internationally mobile, high relative tax burdens on capital incomes will reduce revenues.

As a consequence, countries are forced into tax competition, regulatory competition and wage competition to defend or improve their shares in the world markets for goods and services, their attractiveness as a location for productive investments, and their ability to collect revenue from mobile tax bases. This much is generally accepted. The question is whether and how these conditions will affect the employment and social-policy goals of advanced welfare states as they had been defined at the end of the postwar golden age. 


\section{General challenges}

In discussing this question, it is useful to distinguish between general challenges that affect all countries, and the specific vulnerabilities of particular countries or groups of countries. The general challenges will be discussed with regard to their effects on employment and on the financial viability of advanced welfare states.

\section{Employment effects}

Beginning with the effects on employment, it is noteworthy that in the Organization for Economic Co-operation and Development (OECD) average, total employment rates (employment as percentage of population 15-64) in 1998 were at 66.5 percent almost exactly as high as they had been in 1970. There are of course interesting differences between countries to which I will return later. What matters here is that this seeming stability appears as the result of two divergent processes if we distinguish between employment in the sectors that are exposed to, or sheltered against, international competition (Figure 1).

In the exposed sector (which under the conditions of the 1990s includes not only agriculture and industry but also construction, energy supply, transport, communications, financial services and business services - i.e., International Standard Industrial Classification (ISIC) 1-5, 7 and 8), average OECD-18 employment rates declined by almost eight percentage points, from 41.3 percent in 1970 to 33.5 percent in 1997. While there are interesting differences between countries, to be discussed later, the trend is the same: Employment declined steeply in the deep recessions of the mid 1970s and early 1980s. It never returned to its previous volume, even though international trade continued to rise more rapidly than GDP. But as trade increased and national boundaries lost their economic effectiveness, competition in the exposed sectors including competition from producers in low-cost countries - also became more intense. As a consequence, firms in countries with high labor costs were forced to either move upmarket to less price sensitive quality products, or to use all available organizational and technical options to cut production costs through labor-saving rationalization. In either case, skill requirements would rise, and the total volume of employment would decline.

Losses in industry, it is true, were in part compensated by the expansion of production-related services and increases in the final consumption of communications and financial services (which are also included in our definition of the exposed sector). Here again, some countries have done better than others. But these services are now also affected by the rapid advance of information and communications technology and, in any case, their rise is not enough to fully compensate the loss of production jobs. Nevertheless, if total employment rates recovered after each recession and, on average, are now as high as they were in 1970, the effect is entirely due to the continuous rise of employment in the sheltered sector - also by almost eight percentage points, from 25.9 percent in 1970 to 33.6 percent in 1997.

Our definition of the sheltered sectors comprises jobs in "wholesale and retail trade, hotels and restaurants" (ISIC 6) as well as in "community, social and personal services" (ISIC 9) - among which education and health care constitute the largest blocks. Obviously, the category comprises very heterogeneous activities, united merely by the fact that they are more or less immune to international competition because services are locally provided and locally consumed by the ultimate beneficiaries. Beyond that, differences abound: Trade and gastronomical services are generally provided and financed in the private economy, whereas primary 
education is publicly financed and provided in most countries; in health care, privately provided services may be publicly financed on a fee-for-service basis, or publicly provided services may be privately co-financed through user charges. Moreover, some of these services (surgery, for instance) have extremely high skill requirements, whereas others (house cleaning, for instance) may require little specific training. Often, however, high- and low-skill jobs exist in symbiotic interdependence.

As is to be expected, differences among countries matter even more in this heterogeneous sector. What can be said generally is that the more or less inevitable decline of exposed-sector employment could be compensated or even overcompensated only in countries in which conditions were favorable for the expansion of either publicly financed or privately financed local services. But even though sheltered sector employment was not itself exposed to international competition, the conditions which facilitated its expansion were largely shaped by differences in the structures of welfare states which, in turn, were directly affected by the impact of economic integration on their financial viability.

\section{Fiscal effects}

In a nutshell, the story of tightening fiscal constraints is contained in Figure 2, representing average GDP shares of total government outlays, of total revenues from taxes and socialsecurity contributions, and of net public-sector borrowing. ${ }^{3}$ At the end of the postwar golden age, budgets in most countries were in balance or in surplus. With the beginning of the first oil-price crisis, total government outlays increased steeply as countries responded to the threat, or the actual rise, of mass unemployment with deficit-financed investment and spending programs, and in most cases with rapidly increasing social expenditures. As a consequence, average deficits jumped from zero to 2.6 percent of GDP in 1975 and continued at about the same level until the end of the decade. By contrast, revenues from taxes and social security contributions increased more steadily, and continued to do so beyond the end of the decade.

The second oil-price crisis, which began to be felt in 1980s, caused another steep rise of total government outlays to which the initial response was another rise of average public-sector deficits. But now conditions had changed: the monetarist switch of the US Federal Reserve had driven up real interest rates in the international dollar markets from -2 percent in 1980 to +8.1 percent in 1984. Hence the debt service implied by high budget deficits became prohibitively expensive, and fiscal consolidation, which had not been an issue in the cheapmoney environment of the 1970s, became a high political priority. Average deficits declined from a peak of 4.4 percent in 1982 to 1 percent at the end of the decade, and the conservative governments, that had come into office in the 1980s also tried to reverse the seemingly inexorable rise of welfare spending. Nevertheless, total tax revenue continued to rise until 1988. In most countries, in other words, the reduction of public borrowing was at least in part achieved through further increases in taxation.

When the recession of the early 1990s resulted in another and even steeper increase of total government outlays, the pattern changed once more. Now, average tax revenues did not rise at all - in fact, they even declined slightly from their peak in 1988. By default, therefore, publicsector borrowing rose more steeply after 1989 than in any period before - but then it declined

\footnotetext{
${ }^{3}$ Deficits and taxes do notadd up to total outlays since countries also have other sources of income-for instance, revenue from publicly owned enterprises, user charges or co-payments for public services.
} 
just as steeply from its 1993 peak to levels unheard of since the early 1970s. At the same time, total government outlays also declined more steeply than ever before after 1993, even though average unemployment rates remained at record levels, and even though the balance of political power was shifting from conservative to social-democratic governments in the course of the 1990s. The reasons for this implausible coincidence provide the key to an understanding of the present fiscal constraints facing advanced welfare states. I will discuss them separately for borrowing and for taxation.

\section{Borrowing}

For European countries aspiring to membership in the European Monetary Union, the need for rapid fiscal consolidation derived directly from the very restrictive criteria on gross public debt and on public-sector borrowing that were defined in the Maastricht Treaty of 1992 and the subsequent Stability Pact. In order to meet these legal requirements of membership, most countries had to cut expenditures, and if they were unable to raise taxes, they often had to rely on proceeds from privatization to reduce borrowing. For my general argument, however, it is more important to note that fiscal consolidation was equally or even more effective in countries like Sweden, Denmark, the United Kingdom, Australia, and New Zealand that had not aspired to membership in the Monetary Union.

The reason is that in the course of the 1980s all these countries had abandoned capitalexchange controls, so that their currencies were now fully exposed to the volatility of global financial markets and the recurrent waves of currency speculation - whose destructive force (combined with the government's efforts to resist it) had driven Sweden into the deepest crisis experienced by any industrial country in the last three decades. This lesson, which was reinforced by lesser disruptions in New Zealand, Australia and Britain as well as by the Southeast Asian crisis a few years later, has not been lost: Under conditions of complete and instant capital mobility, governments have come to realize that a reputation for "unsound" fiscal policies will not only affect their credit rating and the interest rates they must pay, but will also make their currencies vulnerable to speculative attacks with potentially catastrophic economic consequences. ${ }^{4}$ In short, and even in the absence of Maastricht criteria and IMF pressures, it has become much preferable for governments to be net lenders, rather than net borrowers, in international capital markets.

\section{Taxation of mobile tax bases}

What needs more of an explanation is the fact that, in contrast to earlier recessions, the average GDP-share of tax revenues did not rise at all as total government outlays shot up once again in the early 1990s. Unlike borrowing, after all, taxation was not legally constrained by Maastricht-type obligations in any of countries. Even more remarkably, the flattening of the revenue curves cannot be understood as a "growth-to-limits" phenomenon, since it occurred in low-tax as well as in high-tax countries, and since the difference between countries with the lowest and the highest total tax burdens has remained almost constant from 1970 to the end of the 1990s (see Table 1). In other words, while all countries seem to be constrained on the

\footnotetext{
${ }^{4}$ Among member states of the Monetary Union, the threat is notassociated with speculative devaluation. Butifexcessive national deficits should drive up local demand and local prices, national producers will lose intra-EMU competitiveness. The same is ofcoursetrue of excessive wage increases. For that reason, the stabilitypactis likely to be self-enforcing.
} 
revenue side, there is no evidence of a race to the bottom or, for that matter, of a convergence toward the mean.

Ganghof (2000a; 2000b) ${ }^{5}$ explains this pattern as a result of cross pressures: On the one hand, international tax competition in an environment of highly mobile capital and mobile firms would push governments to reduce the tax burden on mobile tax bases. On the other hand, governments are unable to move very far in this direction because they are simultaneously pushed to reduce budget deficits and confronted by political resistance against measures of welfare-state retrenchment that would have to go beyond the cutbacks that conservative governments had already imposed in the 1980s.

In the literature, the causal effectiveness of international tax competition is in dispute (Swank, 1997; Garrett, 1998). There can be no question, however, that the removal of all barriers to capital mobility has not only provided new opportunities for tax evasion and tax avoidance, but has also created incentives for countries to increase the relative attractiveness of their tax systems for mobile capital. Taxes on interest incomes of non-residents are often reduced to zero in the hope that additional revenue and jobs will be generated by the expansion of financial services. But even in the absence of outright discrimination in favor of non-residents, lower rates may pay off for small countries that will gain more revenue from a larger tax base than they will lose by lowering taxes for residents. That logic also applies to the taxation of corporate profits since companies are free to move their legal residence, or the residence of their financing subsidiaries, to low-tax jurisdictions without having to relocate production facilities as well. As a consequence, all countries have been under pressure to reduce nominal tax rates on incomes from capital interest and on corporate profits, but small countries have been more successful than large countries in maintaining the level of revenue (Ganghof, 2000a).

\section{Taxation of immobile tax bases}

Obviously, tax competition is not only about revenue but also about productive investments, and hence about production and employment - all of which presumably depend on expected posttax profits. Paradoxically, however, here the negative impact of high corporate income taxes is mitigated if firms are in fact able to choose the jurisdiction where profits will be taxed regardless of the location of production. But of course these options are not available to all firms. In all firms, however, pre-tax profits must be earned before their tax treatment can be optimized which shifts competitive concerns to the quality and price of labor and other local factors of production. In this context, taxes on labor are thought to play a major role. If they raise the costs of production above the level of competing locations, they should produce disinvestment and job losses.

\section{Impact on employment in the exposed sectors}

Without more evidence, however, the argument is not economically convincing. Why should profits be affected by differences in national factor costs, or even by nationally uniform tax increases (or wage increases, for that matter) except in the very short term? In the exposed sectors, these costs will determine the price, in national currency, of nationally produced goods and services which, in functioning international currency markets, should be reflected in exchange rates with no adverse effects on consumer demand, profits and employment. Even

\footnotetext{
${ }^{5}$ The argument was developed in cooperation with Philipp Genschel (2000).
} 
though currency markets are far from perfect, it should thus not really come as a surprise that the bivariate statistical association between employment rates in the exposed sectors and the total tax burden of OECD-18 countries was extremely weak $\left(R^{2}=0.13\right)$ at the end of the 1990s (Figure 3). In fact, Denmark and Sweden as extreme high-tax countries have relatively more jobs in the internationally exposed branches than the United States as an extreme low-tax country.

For members of the European Monetary Union, however, these data cannot provide much comfort since they do not yet reflect the fact that among them the exchange-rate buffer has been eliminated. For the time being, it is true, even large differences between national levels of taxation should not have an effect on exposed-sector employment if the exchange rates at which national currencies were converted to the Euro were chosen appropriately. But from now on, all changes in factor costs will affect intra-EMU competitiveness. National tax increases (or wage increases, for that matter) that raise relative unit costs of production will produce job losses, and member states will be tempted to cut taxes on labor and other factors of production as a competitive strategy. As in the taxation of incomes from mobile capital, therefore, there is now also a possibility of ruinous competition on social security contributions and "green taxes". 6 It is here, then, that coordination at the European level would be most useful. But these are challenges to be faced in the coming years that are not yet reflected in current practices.

\section{Impact on employment in the sheltered sectors}

If this is true in the exposed sectors, what then is the effect of different levels of taxation on employment in the sheltered sectors? Since a part of these jobs (in education and in health care) is publicly financed in all countries, the overall answer must be ambivalent: There is a moderately positive association $\left(R^{2}=0.38\right)$ of tax levels with public-sector employment (Figure $4)$, and there is an much stronger $\left(R^{2}=0.62\right)$ negative association with private-sector employment (Figure 5) which - since exposed-sector jobs are only weakly affected - must be primarily due to a negative impact of high tax burdens on private services in the sheltered branches. For these, we have to take employment rates in ISIC 6 as a proxy, since services in wholesale and retail trade, restaurants and hotels are privately provided and privately financed in all countries, whereas ISIC-9 employment may be public or private. Here, the impact of taxation is indeed strongly $\left(R^{2}=0.59\right)$ negative (Figure 6). In other words: Countries with high levels of taxation may have high employment rates in the public sector, but they generally pay for this by having fewer jobs in private-sector services.

Why this should be so is, again, not obvious from the perspective of economic theory. In the consumer-oriented services included in ISIC 6, there is no reason to think that private suppliers would be crowded out by public services. Moreover, since foreign competitors play no role here, nationally uniform taxes and other cost factors should merely raise the prices of private services that national consumers have to pay. But that is precisely the problem: Since many of the senvices included here are characterized by relatively low productivity and qualification requirements, consumers often have the option of resorting to self-service, do-it-yourself solutions, and of course to services provided tax-free in the "unofficial economy" (Gershuny 1978). In other words, demand is likely to be price elastic, and the less productive services may be priced out of the private market if production costs are increased through taxes and social

\footnotetext{
${ }^{6}$ The danger is avoided if energy and materials taxes are imposed in the form of higher rates of the value added tax - provided there is no change from the "country-of-destination" to the "country-of-origin principle".
} 
security contributions - or, for that matter, through cost-increasing employment regulations and high minimum wages.

There is also statistical evidence supporting these explanations. For one thing, different types of taxes differ in their impact on the price of the less productive private services. Progressive income taxes, for instance, fall more heavily on medium and high wage jobs than on low-wage services, and they are not collected on incomes below a basic tax exemption (so that wages from low-paid and part-time jobs may not be taxed at all). As a consequence, the statistical association between income taxes and ISIC-6 employment is practically zero (Figure 7). By contrast, consumption taxes will directly increase the price of services, and social security contributions are generally (except in the Netherlands and in Britain) collected as a proportional tax and without an exemption for very low wages. ${ }^{7}$ Unlike income taxes, therefore, they may add a very large tax wedge to the wage costs of services whose market-clearing wages may not be far above rock-bottom reservation wages that are defined by social-assistance benefits. Taking both together, it is not surprising to see a fairly strong negative $\left(R^{2}=0.51\right)$ association between ISIC-6 employment and the aggregate GDP share of consumption taxes and social-security contributions (Figure 8). But these tax effects do not yet tell the whole story.

\section{Other influences}

Taxes are not the only way in which the welfare state affects employment in the sheltered sector. It is of course positively influenced by a Scandinavian-type expansion of publicly financed social services. In the private sector, however, the expansion of service employment may be impeded by egalitarian or protective welfare-state regulations. More specifically, the price of less productive services may be raised above market-clearing levels by the effect which generous social-assistance and unemployment benefits may have on the net reservation wages of economically rational job seekers, or by high statutory minimum wages, or by the solidaristic wage policy of unions (Iversen and Wren, 1998). These effects are reflected in available statistics on wage dispersion. Taking the ratio of incomes in the median and the bottom decile (D5/D1) of the wage distribution as the most appropriate measure, the bivariate association with ISIC-6 employment rates is relatively weak $\left(R^{2}=0.29\right)$, but the influence is clearly in the expected direction (Figure 9).

Similar impediments may be created by regulations increasing the security of present job holders. By raising the anticipated cost of dismissals, rigid rules of employment protection are likely to create disincentives to hiring that will be most significant for small firms and start-ups in service branches where future demand is highly unpredictable. Using an OECD ranking of countries according to the strictness of their employment protection legislation, we find that there is indeed a negative and moderately strong $\left(R^{2}=0.38\right)$ association of Employment Protection Legislation (EPL) ranks with ISIC-6 employment rates (Figure 10).

\footnotetext{
${ }^{7}$ In Germany,jobs with monthly wages of less than DM630 (about320 Euro) per month had beenexempted from social security insurance - with the consequence that estimates of the number ofthese "minor" part-timejobs (which, because they were notcovered bysocial insurance, were notregistered in the officialemployment statistics) ranged between 3 and 5 million, while there existed practically no insured jobs in the wage ranges between DM730 and DM1500 per month.
} 


\section{Summary}

In an international environment of open product and capital markets, countries are constrained in the use of many policy instruments which they had employed in past decades, and they facing new challenges to their employment goals and to the fiscal viability of the welfare state.

In the exposed sectors of the economy, employment rates are stagnant or declining as firms respond to the pressures of more intense international competition and to the more rapid diffusion of labor-saving organizational and technical solutions. Where overall employment gains are being achieved, these are due to an above-average expansion of service branches that are not exposed to international competition.

At the same time, advanced welfare states are now operating under tighter fiscal constraints that have reduced their capacity to resort to deficit financing and to tax incomes from mobile capital and business profits. European countries, moreover, must now also hesitate to increase taxes on less mobile factors of production which will have a direct impact on competitiveness within the Monetary Union, and hence on employment in the exposed sectors of the economy. In addition, countries should also take account of the fact that service employment in the sheltered sectors is negatively affected by high payroll and consumption taxes. As a consequence, average GDP shares of total taxation have stagnated after the late 1980s, and total government outlays have sharply declined after the mid 1990s, even though average unemployment rates were still at a postwar high.

These fiscal constraints have reduced the scope for a further expansion of employment in the public sector, and they have created pressures to reduce the generosity of welfare-state benefits. At the same time, welfare-state regulations and collective-bargaining agreements ensuring high levels of employment protection and egalitarian minimum-wage policies are also under pressure because of their negative impacts on sheltered-sector service employment. In short, there is indeed reason to think that the postwar aspirations and achievements of welfare states committed to full employment, social security and social equality are seriously challenged by the new constraints on national policy choices that are imposed by the international and European integration of capital and product markets.

\section{Differing vulnerabilities}

But if these were the common challenges that confronted all advanced welfare states in the open economies of the 1990s, they had to be faced by countries differing greatly in their structures of employment, taxation and welfare-state benefits. Among the twelve countries covered in our project, not even two are highly similar with regard to these important characteristics. Nevertheless, in describing the most important of these differences, we found it useful to refer to Esping-Andersen's (1990) distinction between Anglo-Saxon, Continental, and Scandinavian welfare states - which, in the postwar decades have been largely influenced by "liberal", "christian-democratic" and "social-democratic" political parties and social philosophies. ${ }^{8}$

\footnotetext{
${ }^{8}$ Switzerland, whose overall performance is better than that of any other country covered by our project, does not fit this classification. Historically, its verylean welfare state corresponded closely to the "liberal" model. Beginning in the late 1970s, however, unemployment insurance, health insurance and earnings-related pension insurance were made compulsory, so thatthe present pattern of welfare-state functions is closer to the Continental model. At the same time, it has combined high levels of "German-type" high-skill employment in internationally competitive exposed sectors with "Anglo-Saxon-type" employment flexibility in sheltered-sector services. Since I
} 
The most important difference among these groups of countries concerns the dividing line between the welfare functions assumed by the state and those which families and individuals are expected to provide for themselves or through the market. Leaving aside primary and secondary education and health care, the most fundamental differences can be described as follows (Figure 11):

- In all three groups of countries, the state is providing social assistance as a safety net assuring a basic livelihood for individuals and families without other sources of income. Even though there is growing support in the literature for an unconditional "basic income" (van Parijs, 1995; Jordan, 1998), existing programs are everywhere meanstested, and able-bodied beneficiaries are generally expected to accept work offers.

In the Anglo-Saxon welfare states, that is essentially the limit of welfare-state benefits as means-testing has been introduced in what were originally "Beveridgean" programs providing flat-rate unemployment benefits and public pensions. In other words, all except the very poor are expected to make private provisions for periods of unemployment and retirement.

- $\quad$ By contrast, Scandinavian and Continental welfare states have gone further in protecting the income status of wage earners by providing earnings-related unemployment benefits and retirement pensions as a public function.

- $\quad$ Finally, the Scandinavian welfare states also assume public responsibility for providing universal social services for all families with small children, for the sick, the handicapped and for the old. In Continental and Anglo-Saxon countries, such services also exist, but they are only available in the context of social assistance for the needy.

As countries differ in the functions assumed by the welfare state, they also differ in the share of resources claimed. As was pointed out above, the distance between low-tax and high-tax countries did not narrow over the last three decades; between Sweden and Australia it now amounts to more than 20 percentage points of GDP (Table 1). As one should expect, the total tax burden is generally highest in the multi-function Scandinavian welfare states, lowest in the lean Anglo-Saxon welfare states and in Switzerland, and intermediate in the Continental countries (Table 2). What is more interesting, in light of the analyses just presented, is that Anglo-Saxon countries and Denmark collect very little revenue from social-security contributions, and depend very heavily on income taxes, while in the typical Continental country this relationship is reversed. There is less of a clear pattern with respect to consumption taxes.

Differences in employment levels and structures are equally substantial (Table 3), with a gap of almost thirty percentage points separating the total employment rate in Switzerland from that in neighboring Italy. In general, total employment is very high or high in Scandinavian and Anglo-Saxon welfare states (with the exception of New Zealand), and relatively low or very low in Continental countries. If we compare public and private-sector employment rates, it is clear that the exceptional employment performance of the Scandinavian welfare states is directly related to their functional profile: Providing universal social services in the public sector, their government employment rates are about twice as high as those of other countries. Since most of the jobs provided in services for families and the aged are filled by women, and since women

cannot do justice to this case here, the reader should refer to Bonoli and Mach (2000). 
are freed from caring duties in the home by the availability of these services, it is also no surprise that participation rates of women in the labor market are highest in the Scandinavian countries (Table 4). ${ }^{9}$ Rates of business employment, by contrast, are somewhat below the OECD average. By the same token, the generally lean Anglo-Saxon welfare states and Switzerland have low public-sector employment rates, but they also have the highest rates of business employment.

Continental countries, however, seem to have the worst of both worlds: employment rates in the public-sector (with the exception of Austria and France) are as low as or lower than those in Anglo-Saxon countries, and employment rates in the private sector are as low as or lower than those in the Scandinavian countries. Here, low government employment rates are explained by low levels of expenditures on social services (Table 4), but the low rates of business employment need more attention. They cannot generally be ascribed to a lack of competitiveness in the industrial sector, since at least Germany and Austria, along with Switzerland, have much higher employment rates in industry than all of the Anglo-Saxon countries, including the United States. As these same countries are also doing quite well in the exposed sectors as a whole (Figure 3), the low level of business employment must be located in sheltered-sector services, for which we again take the ISIC-6 branches as a proxy. There, employment rates are indeed lower in Sweden and in Continental countries (except for Austria and the Netherlands) than they are in all Anglo-Saxon welfare states and in Denmark - which corresponds well with the fact that Continental welfare states and Sweden also have the highest GDP shares of wage-based social-security contributions (Table 2).

With these structural differences in mind, we can finally discuss the characteristic vulnerabilities of advanced welfare states to the challenges of internationally integrated capital and product markets that became fully manifest in the 1990s.

\section{Scandinavian countries}

In the Scandinavian countries, the range of functions assumed, and the share of societal resources claimed by the welfare state are the most extensive. It would be plausible to expect, therefore, that they would also be most affected by the fiscal constraints of international capital mobility and tax competition. In fact, however, social spending continued to rise in Denmark during the 1990s, and while in Sweden it had again fallen below the 1993 peak, it still was higher than in any other OECD country. Moreover, both countries were running budget surpluses by 1998, and revenue from personal and corporate income taxes (which supposedly should be most vulnerable to international tax competition) were also the highest among OECD countries and did actually rise after the mid 1990s. The explanation of this remarkable fiscal performance is clearest in Sweden, which has switched to a "dual income tax" by which all incomes from capital are taxed at a uniform low rate, while personal incomes from work continue to be subject to a steeply progressive tax with very high top rates. In Denmark, the same result is achieved by a more complex pattern of rules and exceptions that reflect the fact that capital in the Danish economy with its large share of family-owned small firms is less mobile than it is in Sweden (Ganghof, 2000a). In other words, the present revenue bases of the Scandinavian

\footnotetext{
${ }^{9}$ It should be noted, however, that female participation rates are also above average in Anglo-Saxon countries with verylow public-sectoremployment, but high employmentrates in private-sector services. In fact, there is an extremely high statistical association $\left(R^{2}=0.75\right)$ between female participation rates and employment in the sheltered sector (ISIC 6+9) as a whole (Daly, 2000).
} 
welfare state are no longer vulnerable to international capital mobility - but they might be politically vulnerable to tax resistance.

On the employment side, there is no question that the exceptional performance of Denmark and Sweden is primarily owed to extremely high rates of public-sector employment which are due to a rapid expansion of social services from the 1960s to the mid 1980s. Considering only services for families, for the disabled and for the aged, expenditures in Denmark and Sweden exceed those in all other countries by at least four percentage points of GDP — which also suggests that total social expenditures for other purposes are entirely within the normal range of Continental European countries (Table 4).

Business employment is somewhat below the OECD average (and in Sweden it is still affected by the deep recession of the early 1990s). But it is noteworthy that in spite of extremely high total tax burdens, employment rates in industry and in the exposed sectors as a whole are also as high or higher than the OECD-18 average. If there is reason for concern, therefore, it must focus on below-average employment rates in private-sector services in the sheltered sector, for which we again take ISIC-6 as a proxy (Table 3). Here, Denmark and even more so Sweden are indeed below the OECD average. One reason is that generous social benefits and strong unions committed to an egalitarian distribution of primary incomes have achieved the lowest rates of D5/D1 wage dispersion in the OECD (Table 4 and Figure 9). The remaining difference between Sweden and Denmark is in part explained by the fact that the GDP share of combined revenues from social contributions and consumption taxes is significantly higher in Sweden than it is in Denmark (Figure 8). It should also play a role, finally, that employment protection in Sweden is very rigid, whereas dismissal rules in Denmark are almost as "liberal" as they are in the Anglo-Saxon countries (Figure 10).

As a consequence, the continuing viability of the Scandinavian model of work and welfare depends critically on high levels of public-sector employment. From what was said above, it follows that these are not challenged by international tax competition or by international competition in product and investment markets ${ }^{10}$, but they might be challenged by political tax resistance. So far, however, there is no evidence of that in the revenue statistics or in political practice. Even though public opinion polls suggest that dissatisfaction with the tax system is high and may be increasing in Sweden (Edlund, 2000), ${ }^{11}$ nevertheless the Social Democrats were able to return to office in 1994 with a campaign promise of higher taxes on incomes. In Denmark, opinion surveys even suggest that more than two thirds of the Danes are content with the existing level of taxation (V.A. Schmidt, 2000). It appears, therefore, that the universal benefits ensured by the Scandinavian welfare state, and in particular the universal social services and the jobs which they provide, have also created the political constituencies among middle-income groups that defend it against demands for retrenchment (Svallfors, 1999). As long as this political support holds up, there is no reason to think that the Scandinavian model cannot be maintained in the open economy.

\footnotetext{
${ }^{10}$ Since Sweden has relatively high GDP shares of social-security contributions, it would becomevulnerable if it should join the European Monetary Union, whereas Denmark would be totally safe on that score.

${ }^{11}$ Itis interesting to note that in 199753 percentofrespondents (as compared to 42 percentin 1991) thought that taxes are too low for high-income groups (Edlund,2000, Table 2). This may suggest that the move to a "dual income tax" that privileges capital incomes is perceived as violating egalitarian values.
} 


\section{Anglo-Saxon countries}

In the Anglo-Saxon countries, by contrast, middle-income individuals and families have long had to rely on private provision for a wide range of insurance and service functions that are performed by the state in Scandinavian countries. Thus, welfare state spending had traditionally been very low in Australia and New Zealand, where full employment policies and wage regulation had constituted an "informal welfare state" instead (Schwartz, 2000). In the United Kingdom, the tax-financed National Health Service had pushed up the GDP share of social spending, but the level was still below that of Continental, let alone Scandinavian welfare states. At the same time, overall tax burdens remained low, and while the share of corporate and personal income taxes is comparatively high, their impact on international tax competition was largely neutralized through tax reforms in the 1980s that combined reductions of nominal rates with base broadening (Ganghof, 2000a).

As a consequence of the lean welfare state, public sector employment had always been very low in Australia and New Zealand; in the United Kingdom, where it had risen until 1979, it was subsequently reduced to similarly low levels. Thus generally high rates of total employment are achieved in the private sector. Industry, however, had not been internationally competitive in the postwar decades, and had declined dramatically in the 1970s. In all three countries, moreover, the monetarist and neo-liberal turnaround of the 1980s resulted in further massive job losses that only bottomed out in the 1990s. On balance, the losses in industry could not be compensated by gains in other branches of the exposed-sector, even though financial and business services did benefit from the radical liberalization and deregulation of capital and product markets. In any case, these gains did almost exclusively benefit high-skill and highwage groups among the work force, rather than workers whose jobs in industry were being destroyed.

If Anglo-Saxon welfare states nevertheless have relatively high total rates of business employment, their success is mainly due to above-average employment rates in private-sector local services (Table 3) - which are also reflected in above-average participation rates of women (Table 4). In these less productive service branches, expansion is structurally facilitated by very low levels of social-security contributions (Table 2), by low levels of employment protection (Figure 10), and by extremely decentralized or even individualized processes of wage determination. The downside of highly flexible wages and employment conditions is, however, a growing population of "working poor" whose market-determined wages are at or below subsistence levels.

For Anglo-Saxon societies (whose commitment to their specific postwar welfare goals is not necessarily weaker than it is on the Continent or in Scandinavia), this rise of poverty constitutes a moral, and at the same time a practical problem: Even though they are "lean" in terms of the overall functions assumed by the state, and generally "mean" in terms of benefit levels (Rhodes, 2000), social assistance as a last resort is similar to Scandinavian and Continental programs, and in fact quite generous for low-income families with small children (Table 4). For low skilled workers, therefore, these benefits are likely to be higher than the wages they could earn in less productive service jobs. Under these conditions, the fact that social assistance benefits are means-tested may impose a prohibitive tax on earned incomes. The resulting unemployment traps would then not only frustrate efforts to reduce social expenditures, but would also increase the number of children growing up in poverty and socialized in "workless families". 
In coping with these severe risks to the Anglo-Saxon welfare state, all three countries are generally turning to "workfare" solutions which replace unemployment benefits with training and "job-seeker allowances" for single workers, and which allow the combination of wage incomes with "in-work" welfare benefits for families. If fully developed, such combinations of flexible and unprotected low-wage labor markets with benefit programs applying the logic of the negative income tax may indeed allow high levels of total employment to be realized in the private sector without a dramatic increase in inequality and poverty. However, as the expansion of the Earned Income Tax Credit in the United States has demonstrated, if they are to be effective in their own terms, such programs cannot be cheap.

As is true of the Scandinavian model, therefore, the viability of Anglo-Saxon welfare states that attempt to remain true to their Beveridgean aspirations is not challenged by the international economy or by tax competition. If there is a challenge, it is again political. But here, conditions differ. In the Scandinavian welfare states, the majority of middle class voters are defending universal social insurance benefits, universal social services and the associated jobs when they resist proposals for welfare-state retrenchment. In Anglo-Saxon countries, by contrast, middleclass voters - who do not expect to become dependent on social assistance, and who are bearing the costs of private provisions for expected contingencies - have no self-interested motive to pay higher taxes in order to improve purely redistributive welfare programs. In other words, and perhaps paradoxically, the political discourses defending the generous Scandinavian model may succeed by appeals to enlightened self-interest; in Anglo-Saxon countries, by contrast, any extension of the lean and mean welfare state must depend on appeals to solidaristic morality.

\section{Continental countries}

With regard to international challenges, however, the comprehensive Scandinavian welfare states and the lean Anglo-Saxon welfare states appear to be equally viable. Moreover, both models are compatible with high levels of employment in sheltered-sector services that are able to compensate for stagnation or decline in the exposed sectors. Neither of these statements would generally apply to the Continental welfare states.

By and large, it is true, personal and corporate income taxes, which are potentially most vulnerable to international tax competition, play a comparatively minor role in the revenue structure of Continental countries (Table 2). Nevertheless, nominal rates may still be high since these taxes are often collected from a very narrow base. Where that is true, demands for tax cuts tend to be stronger than political support for base broadening or for a dual income tax with the result that "tax reforms" responding to perceived international competition may further reduce already low revenues from income taxes - as was true of Germany, the Netherlands and Belgium after the mid 1980s.

By contrast, revenues from social security contributions, which are not directly vulnerable to international tax competition, are generally high or very high in Continental welfare states, and they were further increased in the 1990s in Austria, Germany and Italy (and in Sweden). As I pointed out above, however, such changes will have a major impact on competitiveness in product markets once the exchange-rate buffer is removed. Since all Continental welfare states covered by our project are now members of the European Monetary Union, their financial dependence on social-security contributions has turned into a massive fiscal constraint: If it is disregarded, employment in the exposed sectors will suffer; if it is respected, social spending 
will need to be contained, and may have to be reduced if competitor countries choose to cut their own contribution rates. ${ }^{12}$ In other words, Continental welfare states will in the near future become very much vulnerable to international tax competition, even though these effects cannot yet be observed in empirical studies.

For the time being, the main problems of Continental welfare states are generally low rates of total employment (Table 3) that no longer provide sufficient jobs for all those who need or want them - which includes core workers who lost their jobs in the overall decline of industrial employment as well as outsiders, in particular women, and in some countries, young job seekers who are unable to enter the labor market. These problems are closely related to the characteristics of Continental welfare states that emphasize the protection of existing jobs of the core workforce as well as relatively attractive social insurance benefits for core workers who lose their jobs. Thus, the effects of industrial decline were mitigated by the exit options of disability and early-retirement pensions (Ebbinghaus, 2000), whereas active measures that would have improved employment opportunities and incentives for women were generally low on the agenda of governments and unions (Daly, 2000). As a consequence, Continental countries have the lowest employment rates of older workers as well as the lowest participation rates of women (Table 4).

It needs to be emphasized, however, that the characteristics of Continental welfare states do not necessarily undermine international competitiveness. Continental employment rates in industry (Table 3) and in the exposed sectors as a whole (Figure 3) vary considerably, but in both regards, Austria and Germany, are together with Switzerland and Denmark, are among the high performers - and in any case doing better than the United States. On the other hand, exposed-sector employment is particularly low in Belgium, Italy and France, which suggests that factors unrelated to the structure of welfare states must be decisive here - among them the historical legacies of industrial specialization and past industrial policies, and perhaps also of confrontational industrial relations. By contrast, the general weakness of Continental countries in sheltered-sector employment is indeed explained by the characteristic structures of their welfare states.

With the exception of France and Austria, government employment in Continental countries is as low or lower than it is in Anglo-Saxon countries and, in any case, far below the Scandinavian level. The main reason is that in the Continental tradition, caring services for the young, the handicapped and the old are not generally treated as a welfare-state function, but are primarily performed by mothers, wives and daughters in the family. ${ }^{13}$ Hence public expenditures on these social senvices are much lower than they are in Scandinavian countries (Table 4). ${ }^{14}$ In contrast to the Anglo-Saxon countries, moreover, service employment in the private sector was also constrained by the structures of Continental welfare states.

\footnotetext{
${ }^{12}$ Itshould be understood thattheseareceteris-paribus propositions. Ofcourse, ratecuts mayberefinanced from other sources, and wage cuts may substitute for rate cuts in international cost competition.

${ }^{13}$ In France and Belgium, public child-care facilities are more generally availablethan in other Continental countries (Daly,2000), and in Germany, the recentintroduction ofcompulsorylong-term care insurancehas extended publicly financed services for the aged (Alber, 2000).

${ }^{14}$ Expenditures in Germany and the Netherlands are not fully reflected in government employment data, since publicly financed or subsidized social services are to a large part provided by not-for-profit organizations.
} 
With the exception of Austria and the Netherlands, ISIC-6 employment rates in all of them are well below the OECD-18 average. After what has been said above, the reasons are fairly clear: In all countries, the tax wedge of high social-security contributions increases the costs and reduces the private market for price-elastic consumer and personal services (Table 3). In addition, employment protection legislation is generally very strict in Continental countries (Figure 10), and in some countries union wage policies or government minimum-wage legislation have reduced D5/D1 wage differentials to almost the Scandinavian level (Table 4). This composite explanation is not contradicted by the two exceptional countries: In Austria, wage differentials are unusually high, and the Netherlands have not only somewhat more liberal employment-protection rules, but have also integrated social-security contributions into the income-tax schedule - with the effect that the basic tax exemption reduces the cost burden on part-time and low-wage jobs.

\section{Conclusion}

This overview of the findings of an extremely complex comparative project could only highlight very basic patterns. Nevertheless, even at this level of simplification, the basic message seems worth telling: In the 1990s, the international and European integration of capital and product markets has replaced the postwar regime of "embedded liberalism". As a consequence, nation states are no longer able to use a wide range of policy instruments that had depended on control over their own economic boundaries. These constraints are particularly tight for member states of the European Union and of the European Monetary Union. Countries must now defend or regain the competitiveness of their exposed sectors in highly contested international product markets; they must maintain or restore the attractiveness of national locations for profit-seeking investments; and they must cope with the impact of high capital mobility on their revenue bases. As a consequence, all welfare states are operating under tighter fiscal constraints, and all have to cope with stagnant or declining rates of employment in the exposed sectors of their economies. If the level of total employment is to be maintained or increased, that can only be achieved through an expansion of public or private-sector services in the sheltered sectors.

In all countries, the defense of economic viability in an environment of internationally integrated product and capital markets did and does require difficult and painful policy adjustments. The question is whether these must endanger political legitimacy by violating the values embedded in postwar commitments to full employment, social security and social equality. The answers are necessarily contingent on the success or failure of policy learning and policy discourses in each country. Nevertheless, our analysis of characteristic vulnerabilities suggests that the difficulties differ considerably among groups of countries.

From the analyses presented here it would follow that Scandinavian and Anglo-Saxon welfare states, though being extremely different, have a chance to achieve these adjustments within the basic normative and institutional frameworks of their postwar models. They should be able to maintain economic viability and political legitimacy without re-engineering the basic structures of their policy legacies. For Continental countries, by contrast, the challenges are more difficult to meet.

Under conditions of the Monetary Union, their traditional revenue base will become vulnerable to new competitive pressures, while a shift to - economically feasible - higher income taxes would violate the Zeitgeist of current tax reforms. Moreover, it is more difficult for them to compensate employment losses in the exposed sectors by an expansion of sheltered-sector 
services. There are no strong political demands for "Scandinavian" levels of publicly financed social services, and if there were, it would be hard to accommodate them under present fiscal constraints. At the same time, there is strong political opposition against an "Anglo-Saxon" deregulation of private-sector services, even if incomes from low-wage jobs were publicly supplemented. As a consequence, overall employment rates and female participation rates remain lowest in the Continental group of countries. It is at least uncertain, however, whether this state of affairs can remain economically viable and politically legitimate in societies which are rapidly aging and where the acceptance of traditional gender roles is rapidly eroding.

\section{References}

Alber, Jens. 2000. RecentDevelopments ofthe German Welfare State:Basic Continuityora Shiftof Paradigms? Ms. University of Konstanz.

Bonoli, Giuliano; André March.2000. "Switzerland. Adjustment Politics within Institutional Constraints." In: Fritz W. Scharpf and Vivien A. Schmidt, eds., Welfare and Work in the Open Economy. Vol. II. Diverse Responses to Common Challenges. Oxford, Oxford University Press, pp. 131-172.

Daly, Mary. 2000. "A Fine Balance. Women's Labor Market Participation in International Comparison." In: Fritz W. Scharpf and Vivien A. Schmidt, eds., Welfare and Work in the Open Economy. Vol. II. Diverse Responses to Common Challenges. Oxford, Oxford University Press, pp. 467-510.

Ebbinghaus, Bernhard. 2000. "Any Way Out of 'Exit from Work'? Reversing the Entranched Pathways of Early Retirement." In: Fritz W. Scharpf and Vivien A. Schmidt, eds., Welfare and Work in the Open Economy. Vol. II. Diverse Responses to Common Challenges. Oxford, Oxford University Press, pp. 511-553.

Edlund, Jonas.2000. "Public Attitudes towards Taxation:Sweden 1981-1997." Scandinavian Political Studies 23, pp. 37-66.

Ganghof, Steffen.2000a."Adjusting National TaxPolicyto Economic Internationalization.Strategies and Outcomes." In: Fritz W. Scharpf and Vivien A. Schmidt, eds., Welfare and Work in the Open Economy. Vol. II. Diverse Responses to Common Challenges. Oxford, Oxford University Press, pp. 597-645.

-.2000b. "Corporate Tax Competition, BudgetConstraints, and the New Trade-Offs in Domestic Policy. Germany and Italyin Comparative Perspective."Paperprepared forthe2000 Annual Meeting ofthe American Political Science Association, Washington DC, August 31-September 3, 2000.

Garrett, Geoffrey. 1995. "Capital Mobility, Trade, and the Domestic Politics of Economic Policy." International Organization 49, pp. 657-687.

-. 1998. Partisan Politics in the Global Economy. Cambridge, Cambridge University Press.

Genschel,Philipp.2000.“DerWohlfahrtsstaatim Steuerwettbewerb.” MPlfG Working Paper00/5.KöIn,Max-PlanckInstitut für Gesellschaftsforschung. http://www.mpifg.de

Gerschuny, Jonathan I. 1978. After Industrial Society? The Emerging Self-Service Economy. London, Macmillan.

Iversen, Torben; Wren, Anne. 1998. "Equality, Employment, and Budgetary Restraint: The Trilema of the Service Economy." World Politics 50, pp. 507-546.

Jordan, Bill. 1998. The New Politics of Welfare. Social Justice in a Global Context. London, Sage.

Quinn, Dennis. 1997. "The Correlates of Change in International Financial Regulation." American PoliticalScience Review91, pp. 531-551.

Rhodes, Martin. 1996. "Globalization and West European Welfare States: A Critical Review of Recent Debates." Journal of European Social Policy 6, pp. 305-327. 
-.2000. "Restructuring the British Welfare State. Between Domestic Constraints and Global Imperatives."In:Fritz W. Scharpf and Vivien A. Schmidt, eds., Welfare and Work in the Open Economy. Vol. II. Diverse Responses to Common Challenges. Oxford, Oxford University Press, pp. 19-68.

Rodrik, Dani. 1997. Has Globalization Gone Too Far? Washington DC, Institute on International Economics.

Ruggie, John G. 1982. “International Regimes, Transactions, and Change:Embedded Liberalism in the Postwar Economic Order." International Organization 36, pp. 379-415.

Schmidt, Vivien A. 2000. "Values and Discourse in the Politics of Adjustment." In: Fritz W. Scharpf and Vivien A. Schmidt, eds., Welfare and Work in the Open Economy. Vol. I. From Vulnerability to Competitiveness. Oxford, Oxford University Press, pp. 229-309.

Schwartz, Herman.2000. "Internationalization and Two Liberal Welfare States. Australia and NewZealand."In:Fritz W. Scharpf and Vivien A. Schmidt, eds., Welfare and Work in the Open Economy. Vol. II. Diverse Responses to Common Challenges. Oxford, Oxford University Press, pp. 69-130.

Steinmo,Sven.1994. "The End of Redistribution? International Pressures and Domestic Policy Choices."Challenge, Nov-Dec. 1994, pp. 9-17.

Strange, Susan. 1991. “Casino Capitalism.” Kendall W. Stiles, ed., International PoliticalEconomy. AReader. New York, Harper Collins, pp. 109-128.

—.1996. The Retreat of the State. Diffusion of Power in the World Economy. Cambridge, Cambridge University Press.

Svallfors,Stefan.1999."The Middle Class and Welfare State Retrenchment:Attitudes to SwedishWelfare Policies." In: Svallfors, Stefan and Peter Taylor-Gooby, eds., The End of the Welfare State? Public Responses to State Retrenchment. London, Routledge, pp. 34-51.

Swank, Duane. 1997. "Funding the Welfare State:Globalization and the Taxation of Business in Advanced Market Economies." Political Studies 46, pp. 671-692.

Tanzi, Vito. 1995. Taxation in an Integrating World. Washington DC, Brookings Institution.

Van Parijs, Philippe. 1995. Real Freedom for All. What(ifanything) can justify capitalism. Oxford, Clarendon Press. 
Table 1. Taxes and social security contributions as \% of GDP, 1970-1997

\begin{tabular}{|l|l|l|l|l|l|}
\hline & $\mathbf{1 9 7 0}$ & $\mathbf{1 9 8 0}$ & $\mathbf{1 9 8 5}$ & $\mathbf{1 9 9 0}$ & $\mathbf{1 9 9 7}$ \\
\hline United States & 27.4 & 26.9 & 26.0 & 26.7 & 28.5 \\
\hline Australia & 24.2 & 28.4 & 30.0 & 30.6 & 30.4 \\
New Zealand & 27.4 & 33.0 & 33.6 & 38.0 & 36.4 \\
United Kingdom & 37.0 & 35.2 & 37.5 & 36.6 & 35.3 \\
\hline Switzerland & 22.5 & 29.1 & 30.8 & 30.9 & 34.6 \\
\hline Austria & 34.9 & 40.3 & 42.4 & 41.0 & 44.4 \\
Belgium & 35.7 & 43.7 & 46.9 & 44.0 & 46.5 \\
Germany & 32.9 & 38.2 & 38.1 & 36.7 & 37.5 \\
France & 35.1 & 41.7 & 44.5 & 43.7 & 46.1 \\
Italy & 26.1 & 30.4 & 34.5 & 39.2 & 45.0 \\
Netherlands & 37.1 & 45.2 & 44.1 & 44.6 & 43.4 \\
\hline Denmark & 40.4 & 45.5 & 49.0 & 48.7 & 52.2 \\
Sweden & 39.8 & 48.8 & 50.0 & 55.6 & 53.3 \\
\hline OECD 18 & 31.8 & 36.6 & 38.4 & 39.3 & 39.8 \\
\hline
\end{tabular}

Source:OECD Revenue Statistics 1999, Statistical Compendium. 
Table 2. Taxes and social security contributions as \% of GDP, 1997

\begin{tabular}{|l|r|r|r|r|}
\hline & \multicolumn{1}{|l|}{$\begin{array}{l}\text { Total } \\
\text { taxation }\end{array}$} & $\begin{array}{l}\text { Social } \\
\text { security } \\
\text { contributions }\end{array}$ & $\begin{array}{l}\text { Taxes on } \\
\text { goods and } \\
\text { services }\end{array}$ & $\begin{array}{l}\text { Personal and } \\
\text { corporate } \\
\text { income tax }\end{array}$ \\
\hline United States & 28.5 & 6.8 & 4.9 & 11.5 \\
\hline Australia & 30.4 & 2.0 & 8.6 & 17.1 \\
New Zealand & 36.4 & 0.3 & 12.6 & 21.5 \\
United Kingdom & 35.3 & 6.0 & 12.5 & 13.0 \\
\hline Switzerland & 34.6 & 13.1 & 6.1 & 12.8 \\
\hline Austria & 44.4 & 18.0 & 12.5 & 12.9 \\
Belgium & 46.5 & 14.8 & 12.4 & 18.0 \\
Germany & 37.5 & 15.6 & 10.4 & 10.5 \\
France & 46.1 & 20.2 & 12.6 & 8.9 \\
Italy & 45.0 & 15.2 & 11.2 & 16.3 \\
Netherlands & 43.4 & 17.7 & 12.2 & 11.4 \\
\hline Denmark & 52.2 & 1.8 & 17.1 & 31.4 \\
Sweden & 53.3 & 17.7 & 12.0 & 21.6 \\
\hline OECD 18 & 39.8 & 10.9 & 11.2 & 15.7 \\
\hline
\end{tabular}

Source:OECD Revenue Statistics 1999, Statistical Compendium. 
Table 3. Total and sectoral employment as \% of the population 15-64

\begin{tabular}{|l|r|r|r|l|r|}
\hline & $\begin{array}{l}\text { Total } \\
\text { employment }\end{array}$ & $\begin{array}{l}\text { Government } \\
\text { employment }\end{array}$ & $\begin{array}{l}\text { Business } \\
\text { employment }\end{array}$ & $\begin{array}{l}\text { lndustrial } \\
\text { employment }\end{array}$ & \multicolumn{2}{l|}{$\begin{array}{l}\text { Employment } \\
\text { in ISIC 6 }\end{array}$} \\
\hline United States & 73.9 & 10.6 & 63.3 & 11.8 & 16.1 \\
\hline Australia & 68.5 & 10.4 & 58.3 & 9.8 & 17.2 \\
New Zealand & 60.9 & 9.0 & 53.8 & 12.0 & 14.7 \\
United Kingdom & 70.3 & 9.6 & 59.7 & 13.2 & 13.7 \\
\hline Switzerland & 79.8 & 11.1 & 68.8 & 15.7 & 15.2 \\
\hline Austria & 62.8 & 14.3 & 49.1 & 14.5 & 14.4 \\
Belgium & 56.3 & 10.4 & 44.9 & 10.4 & 10.1 \\
Germany & 60.5 & 9.1 & 51.4 & 16.4 & 11.0 \\
France & 59.4 & 14.6 & 44.2 & 11.3 & 9.9 \\
Italy & 50.8 & 8.0 & 42.8 & 12.1 & 10.9 \\
Netherlands & 61.8 & 8.1 & 52.1 & 10.2 & 13.4 \\
\hline Denmark & 75.8 & 22.6 & 52.0 & 14.4 & 12.1 \\
Sweden & 69.6 & 21.2 & 47.8 & 13.5 & 10.6 \\
\hline OECD 18 & 66.5 & 12.6 & 52.7 & 13.0 & 13.0 \\
\hline
\end{tabular}

Sources: Columns 1-3: OECD Economic Outlook; Columns 4-5: OECD Labour Force Statistics. 
Table 4. Selected indicators of welfare state performance 1995-96

\begin{tabular}{|c|c|c|c|c|c|c|}
\hline & $\begin{array}{l}\text { Labor force } \\
\text { Participation } \\
\text { of women } \\
\text { (\%) }\end{array}$ & $\begin{array}{l}\text { Labor force } \\
\text { Participation } \\
\text { of older men } \\
(55-64, \%)\end{array}$ & $\begin{array}{l}\text { Total social } \\
\text { expenditure } \\
\text { as } \% \text { of GDP }\end{array}$ & $\begin{array}{l}\text { Services for } \\
\text { families, the } \\
\text { handicapped } \\
\text { and the aged } \\
\text { as } \% \text { of GDP }\end{array}$ & $\begin{array}{l}\text { Unem- } \\
\text { ployment- } \\
\text { benefit } \\
\text { replacement } \\
\text { low-income } \\
\text { families* }(\%)\end{array}$ & $\begin{array}{l}\text { Earnings } \\
\text { dispersion } \\
\text { (D5/D1) } \\
\text { Both } \\
\text { genders }\end{array}$ \\
\hline United States & 72.0 & 67.6 & 15.8 & 0.36 & n.a. & 2.09 \\
\hline Australia & 64.4 & 59.6 & 15.7 & 0.56 & 82 & 1.64 \\
\hline New Zealand & 68.0 & 69.3 & 18.8 & 0.15 & 77 & 1.73 \\
\hline $\begin{array}{l}\text { United } \\
\text { Kingdom }\end{array}$ & 68.4 & 63.6 & 22.5 & 1.16 & 80 & 1.78 \\
\hline Switzerland & 68.9 & 81.9 & 21 & 0.47 & 88 & 1.58 \\
\hline Austria & 62.4 & 40.7 & 26.2 & 0.85 & 77 & 2.01 \\
\hline Belgium & 52.3 & 33.9 & 27.1 & 0.28 & 76 & 1.43 \\
\hline Germany & 61.0 & 54.6 & 28 & 1.36 & 76 & 1.44 \\
\hline France & 60.7 & 42 & 30.1 & 1.14 & 87 & 1.65 \\
\hline Italy & 42.9 & 55.9 & 23.7 & 0.30 & 46 & 1.75 \\
\hline Netherlands & 60.4 & 44.2 & 27.8 & 1.03 & 86 & 1.56 \\
\hline Denmark & 74.0 & 63.8 & 32.1 & 5.14 & 95 & 1.38 \\
\hline Sweden & 77.9 & 71.3 & 33 & 5.10 & 85 & 1.34 \\
\hline OECD 18 & 61.2 & n.a. & 24.0 & 1.63 & n.a. & 1.65 \\
\hline
\end{tabular}

n.a. = non available

* Single-earner couple with two children;wages attwothirds ofaverage production wage; including unemployment benefits, family and housing benefits; first month of benefit receipt.

Sources: All sources OECD. 
Figure 1. Average $O E C D-18$ employment rates

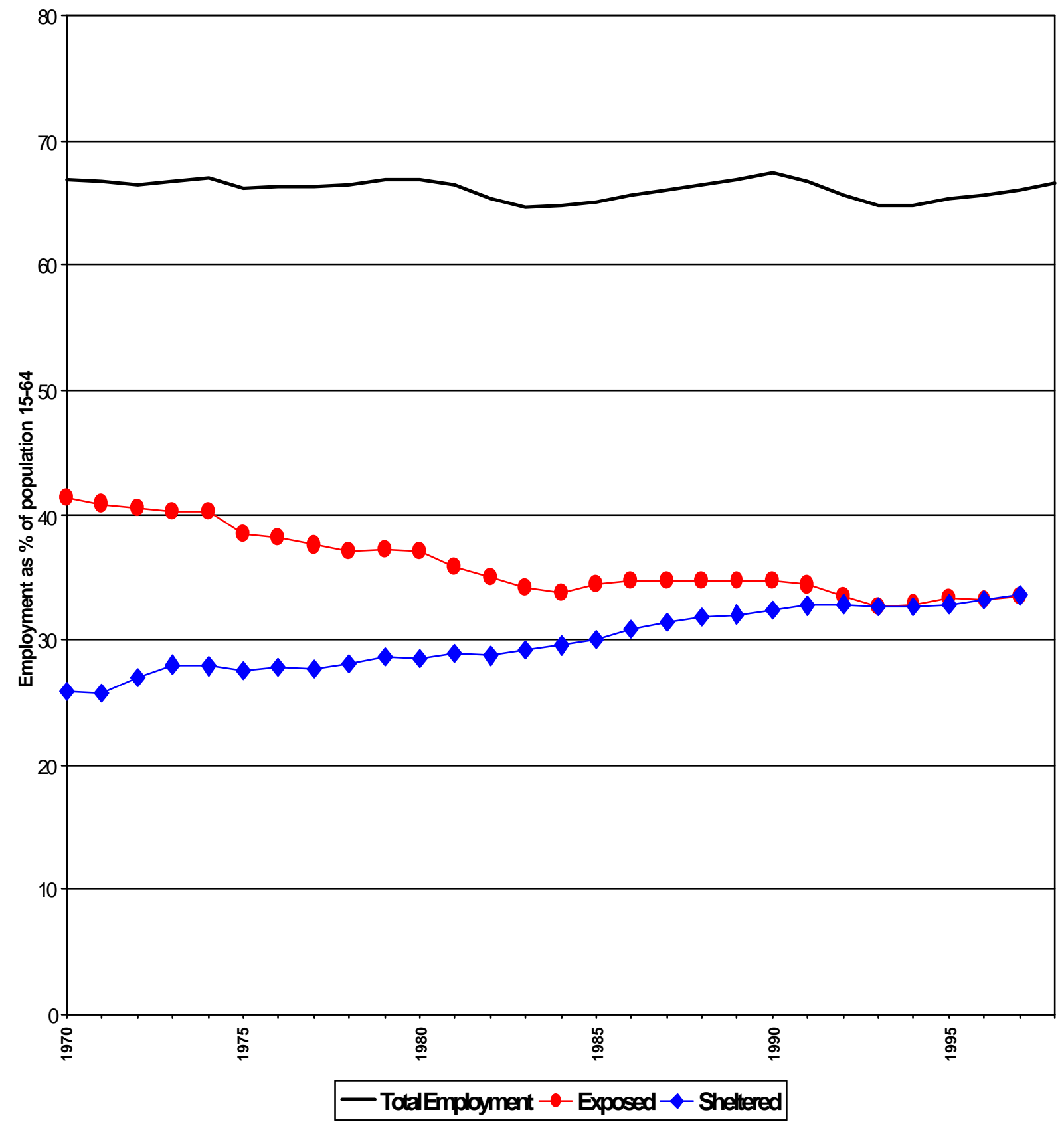


Figure 2. Average $O E C D$-18 fiscal performance

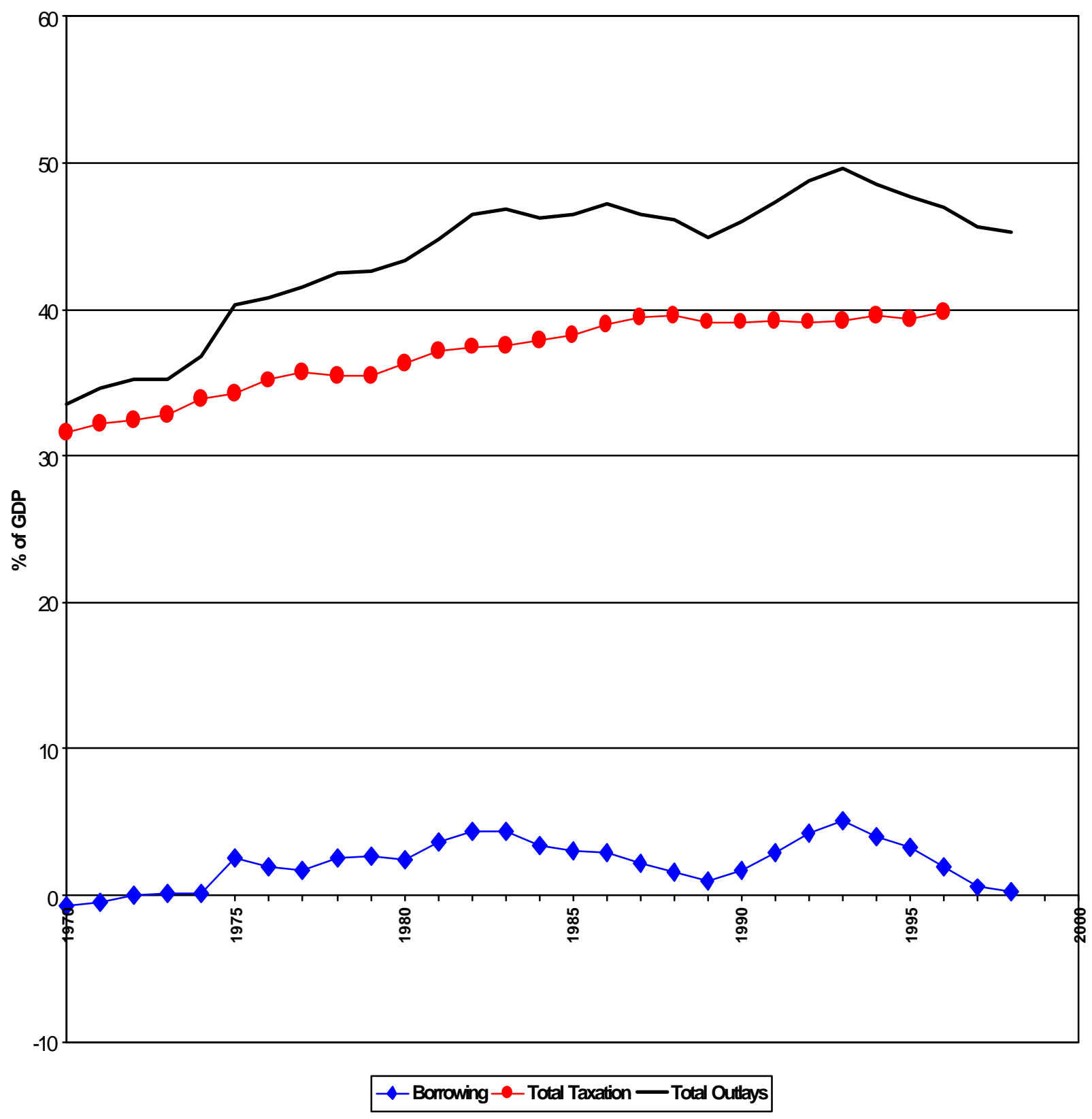

Fritz W. Scharpf 
Figure 3. Tax burden and employment in exposed sectors (ISIC 1-5, 7,8) OECD data for 1997

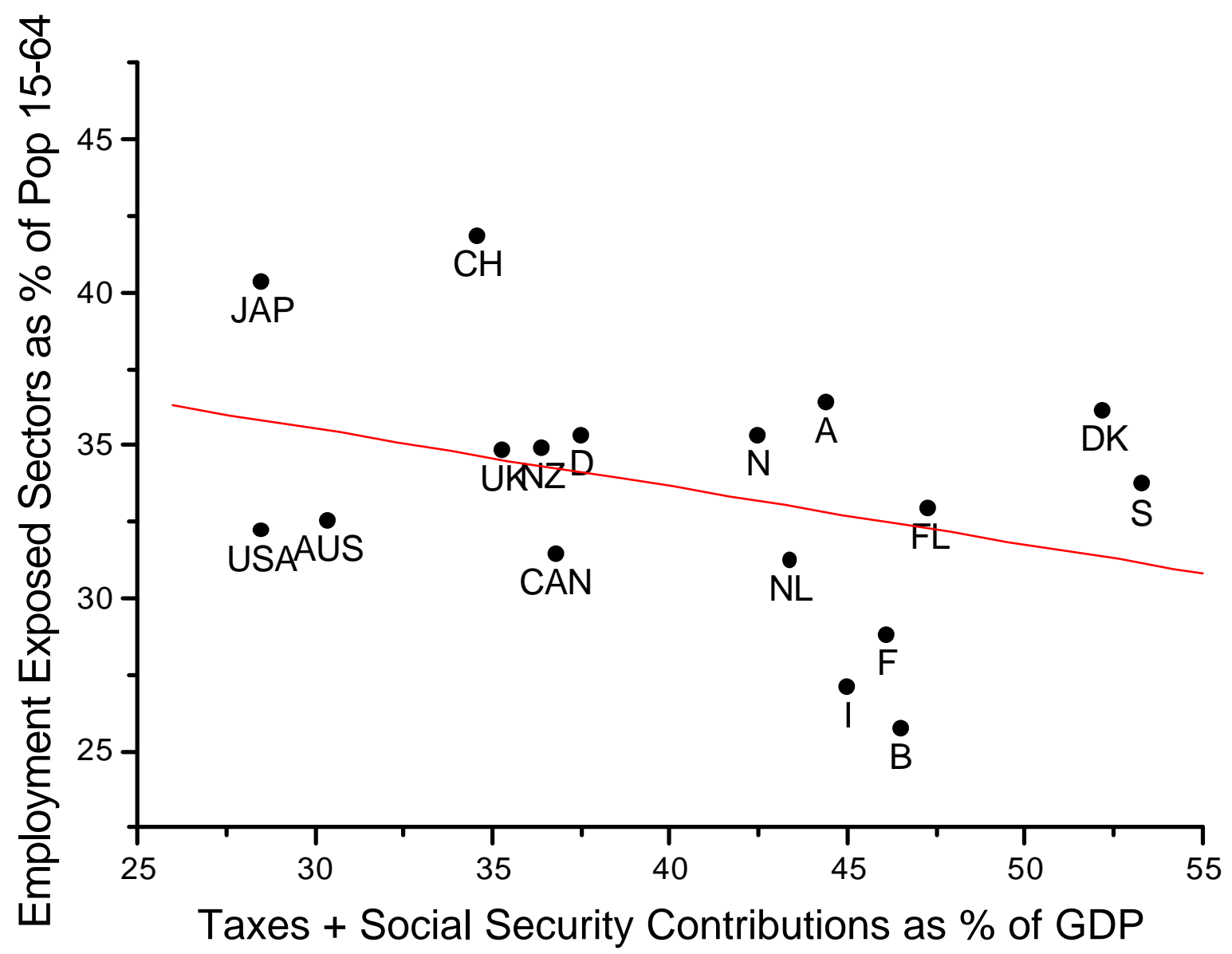

Country codes:

$A=$ Austria

AUS = Australia

$\mathrm{B}=$ Belgium

$\mathrm{CAN}=$ Canada

$\mathrm{CH}=$ Switzerland

$\mathrm{D}=$ Germany

DK = Denmark

$\mathrm{F}=$ France

$\mathrm{FL}=$ Finland
I = Italy

JAP = Japan

$\mathrm{N}=$ Nonway

$\mathrm{NL}=$ Netherlands

$\mathrm{NZ}=$ New Zealand

$\mathrm{S}=$ Sweden

UK = United Kingdom

USA = United States 
Figure 4. Tax burden and public-sector employment. OECD data for 1997

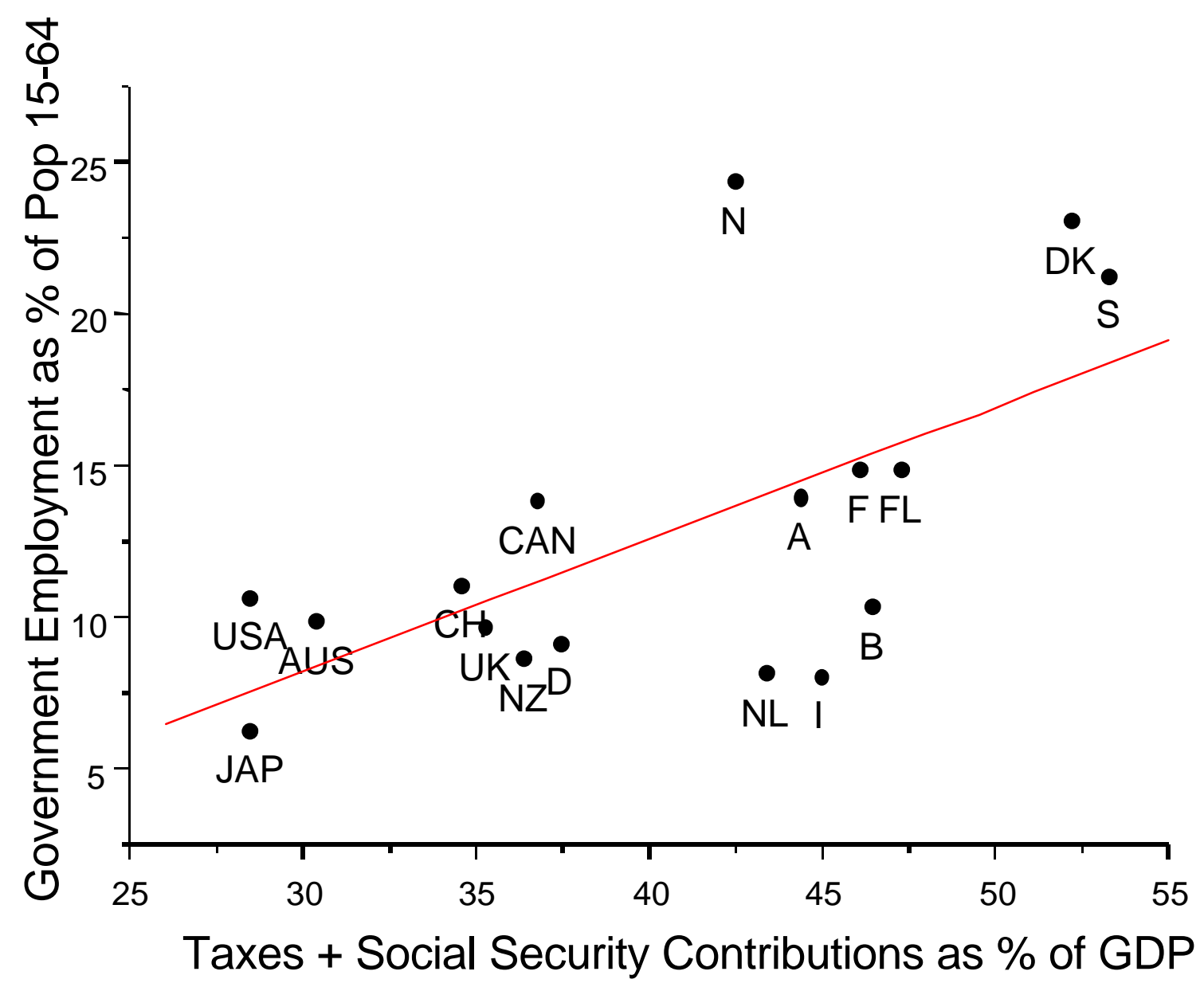


Figure 5. Tax burden and private-sector employment. OECD data for 1997

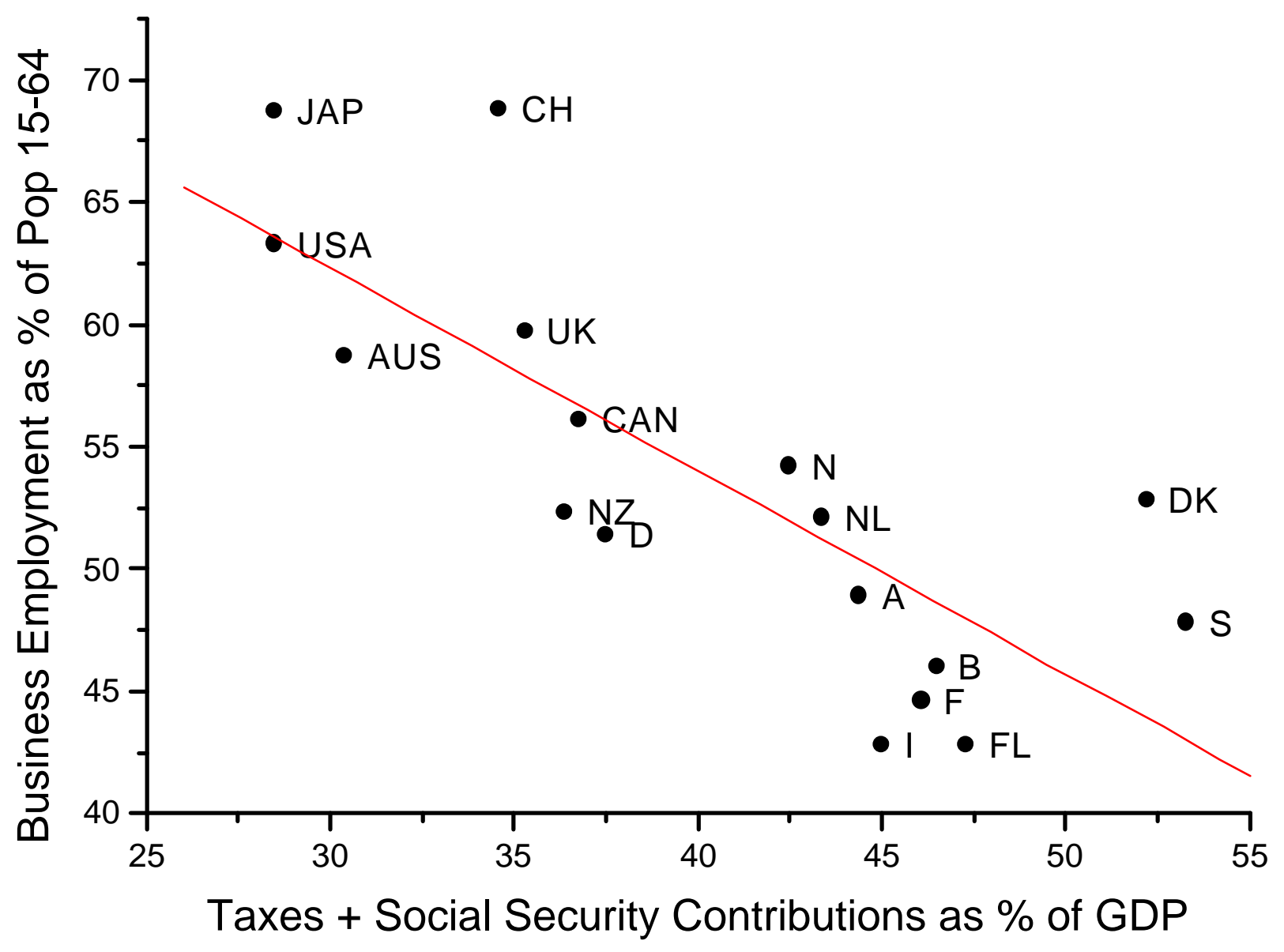


Figure 6. Tax burden and employment in private-sector services. OECD data for 1997

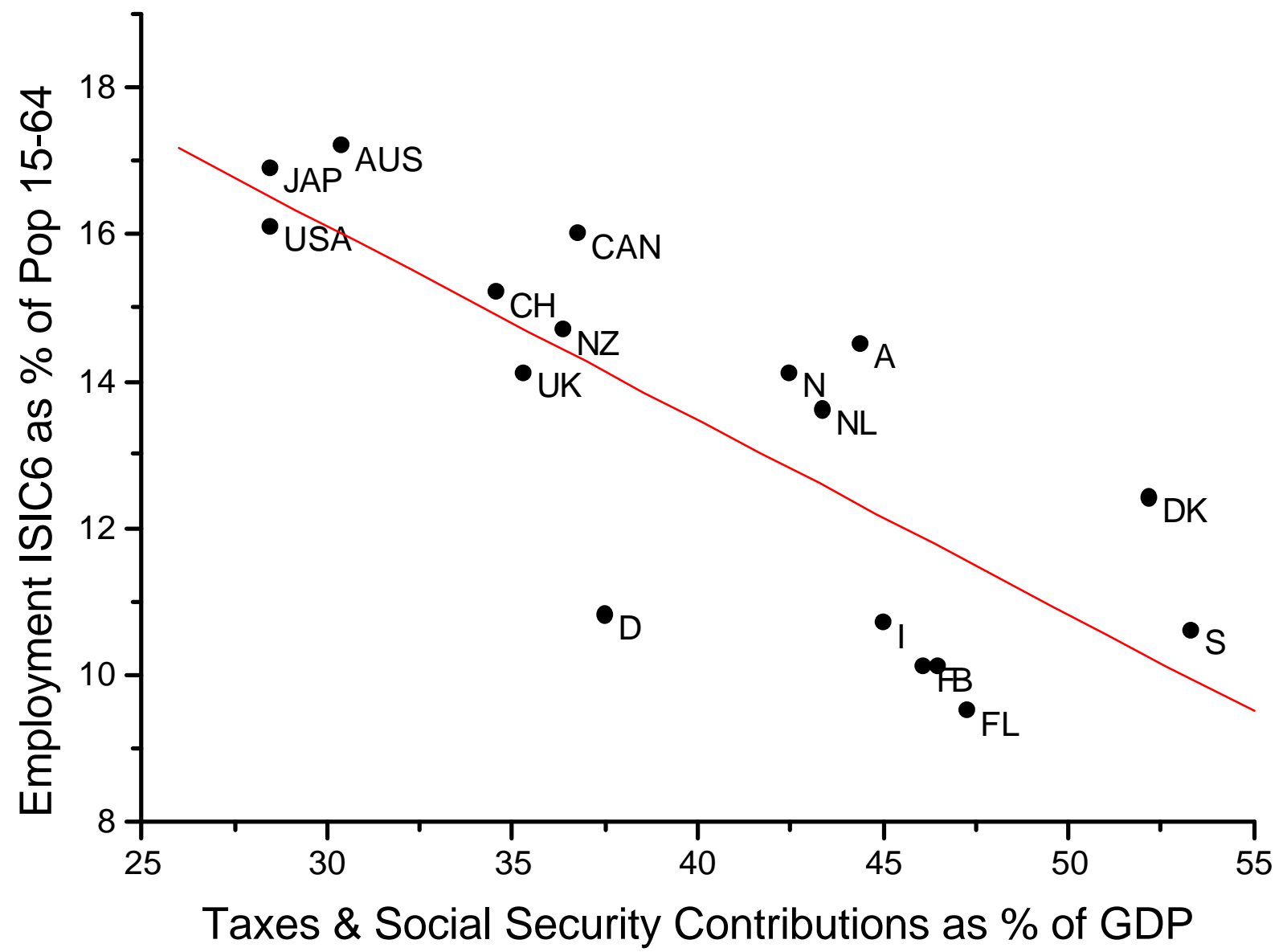


Figure 7. Income taxes and employment in private-sector services. OECD data for 1997

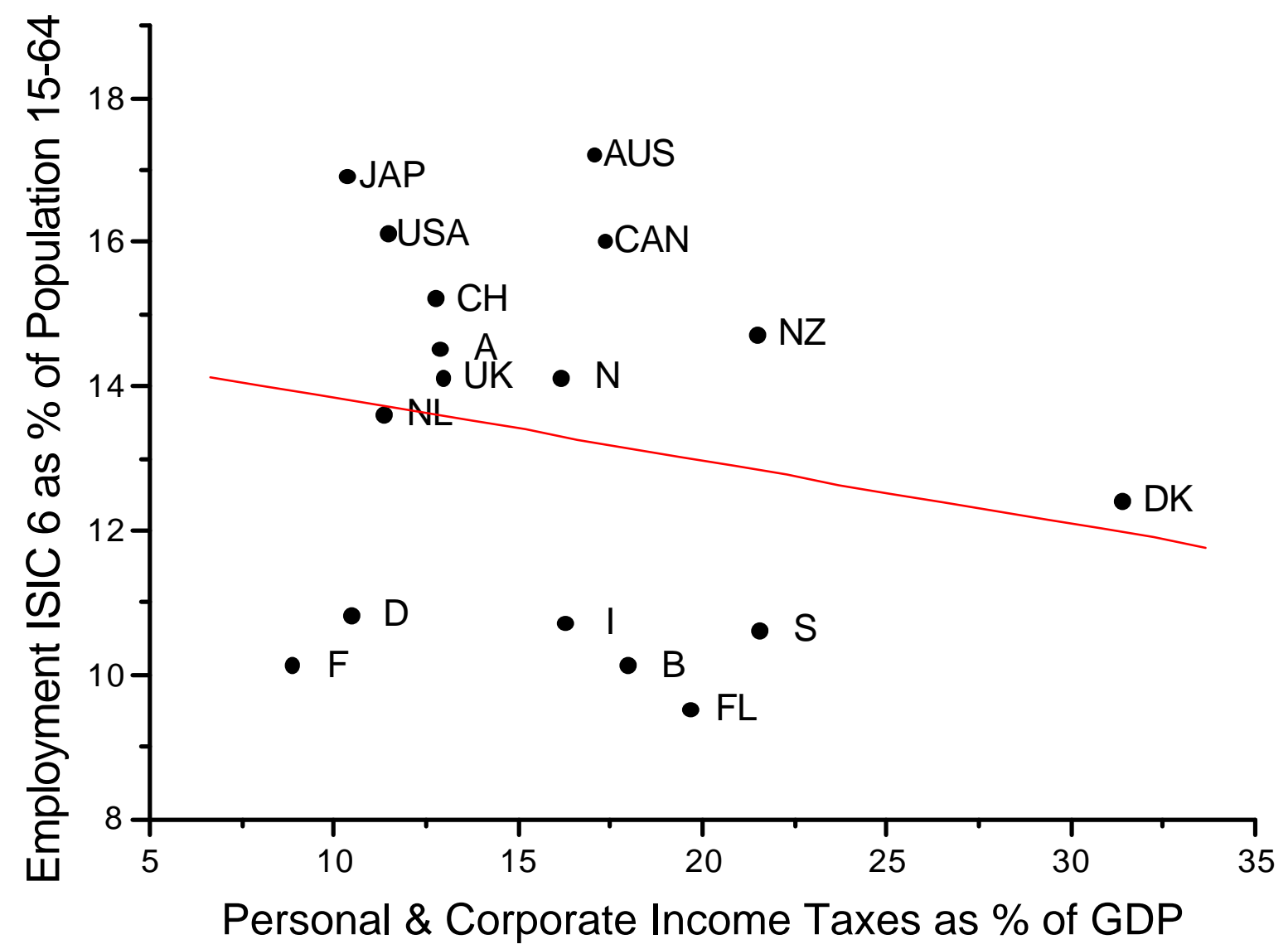


Figure 8. Social security plus consumption taxes and employment in private-sector services. 1997

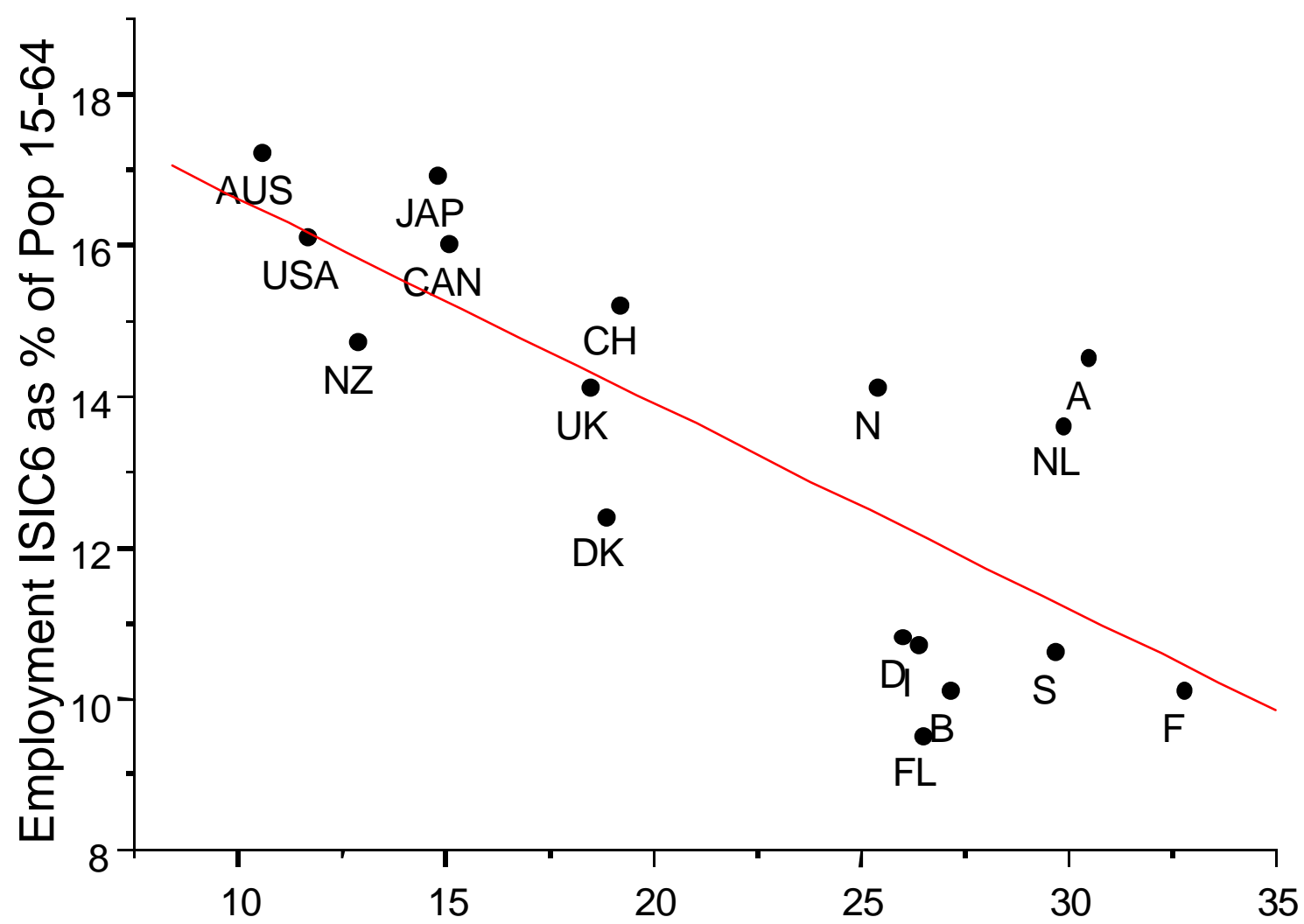

Social Security Contrib. \& Consumption Taxes as \% of GDP 
Figure 9. D5/D1 Wage differentiation (1994-95) and employment in private-sector services (1997)

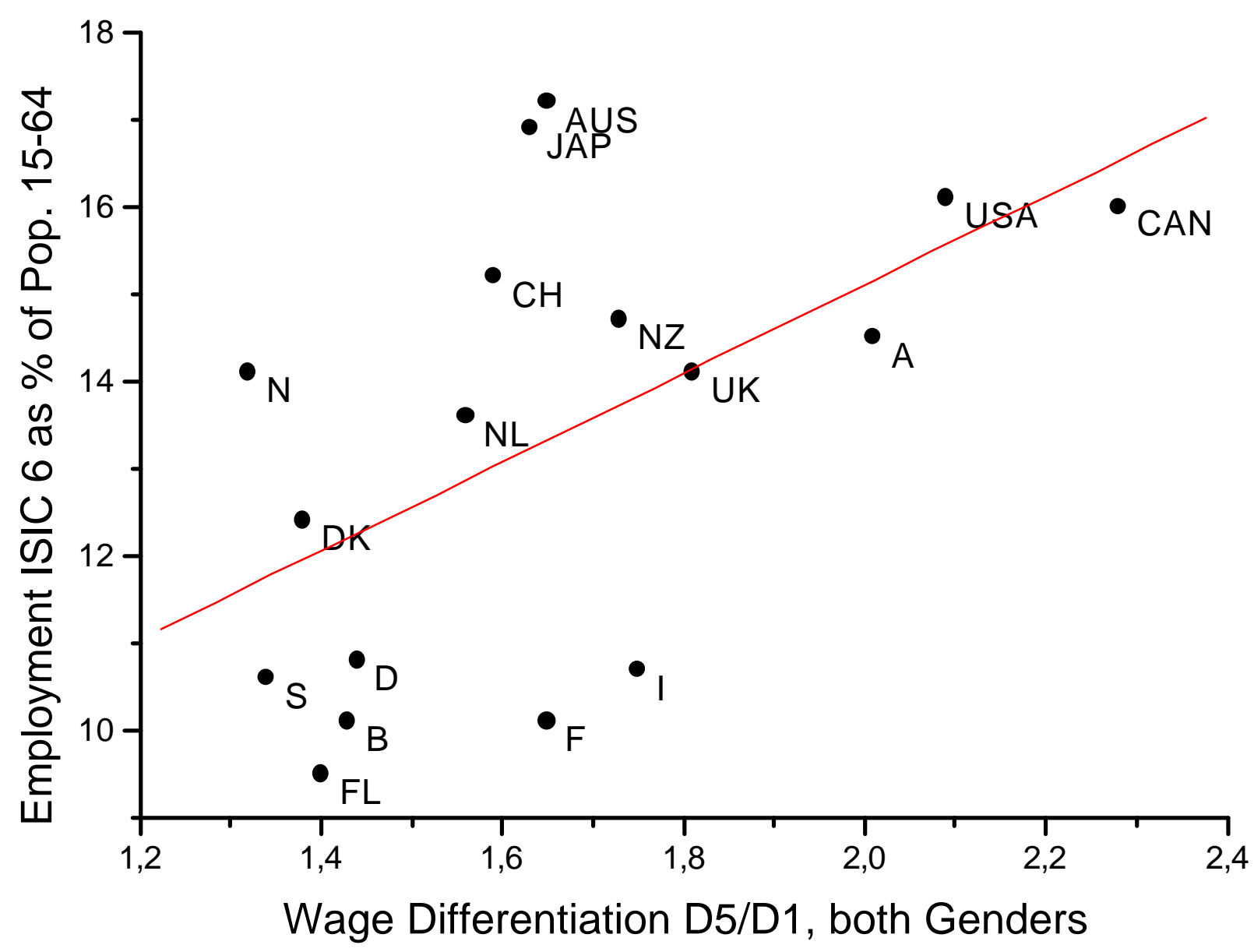


Figure 10. OECD EPL Ranks (1999) and employment in private-sector services (1997)

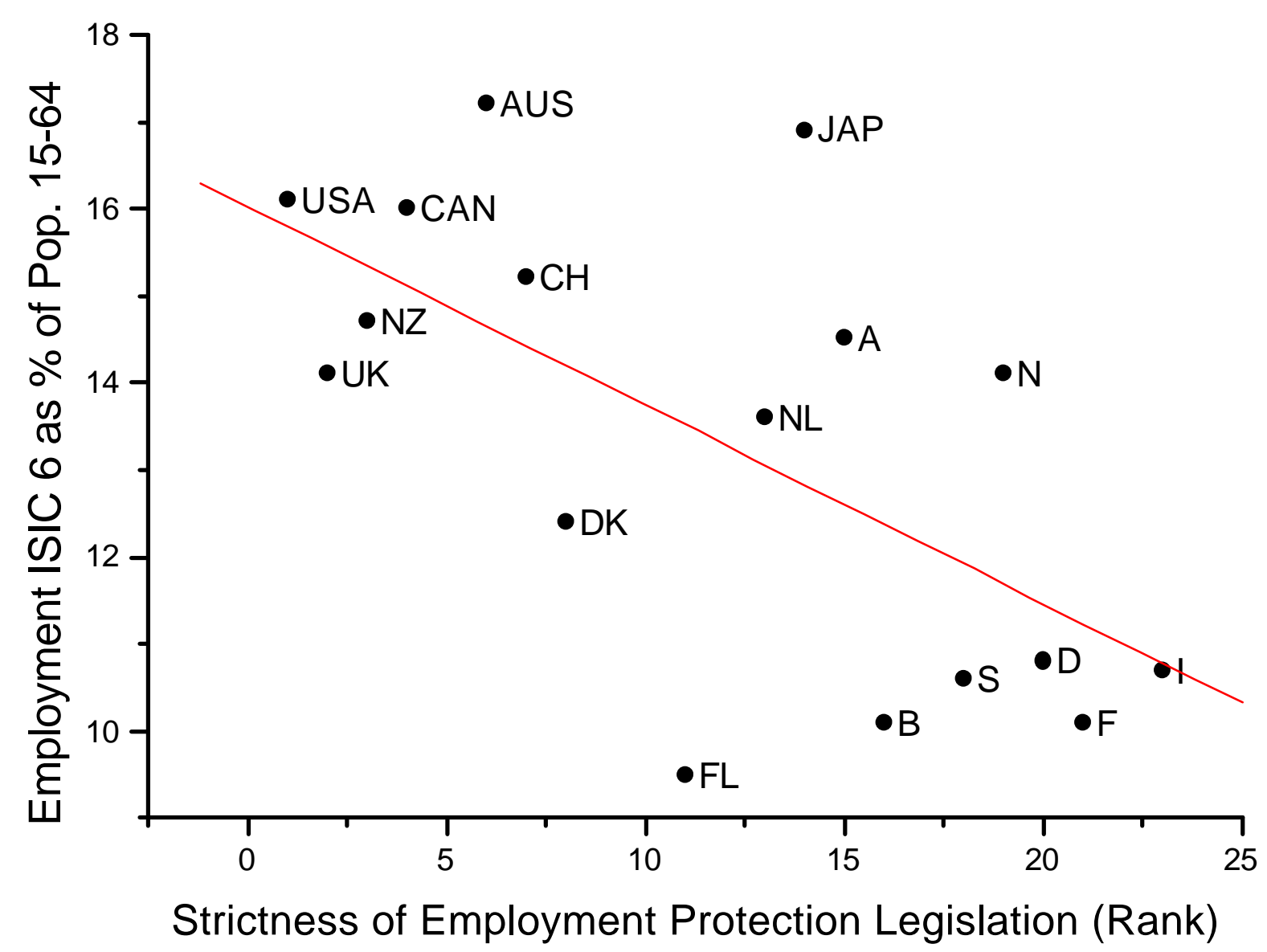


Figure 11. Functional profiles of different types of welfare states
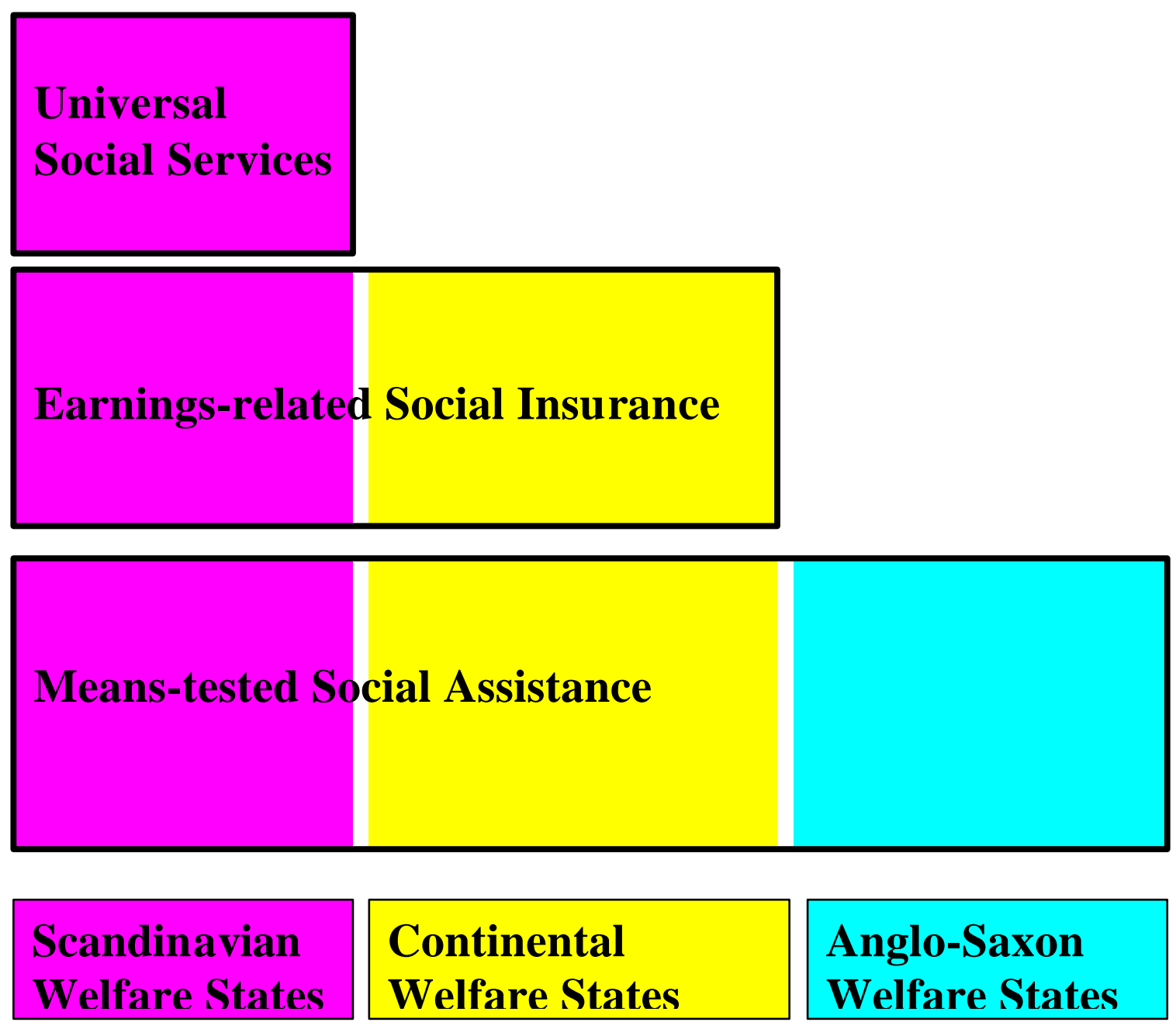

Continental Welfare States
Anglo-Saxon Welfare States 